\title{
Removal of Toxic Elements and Microbial Contaminants from Groundwater Using Low-Cost Treatment Options
}

\author{
Dana A. Da'ana ${ }^{1} \cdot$ Nabil Zouari $^{1} \cdot$ Mohammad Y. Ashfaq ${ }^{1} \cdot$ Mohammed Abu-Dieyeh ${ }^{1} \cdot$ Majeda Khraisheh $^{2}$. \\ Yousef M. Hijji ${ }^{3}$ - Mohammad A. Al-Ghouti ${ }^{1}$
}

Accepted: 13 April 2021 / Published online: 7 May 2021

(C) The Author(s) 2021

\begin{abstract}
Purpose of Review This paper reviews various low-cost treatment techniques such as adsorption, permeable reactive barrier, and biological techniques for the simultaneous removal of chemical and microbial contaminants from groundwater and discusses treatment mechanisms of different treatment techniques. This paper also discusses the challenges of groundwater treatment, how to choose the appropriate treatment technique, and cost analysis of groundwater treatment.

Recent Findings Various treatment technologies have been used for the treatment of groundwater: physical, chemical, and biological technologies with different success rates. In the literature, various adsorbents have been successfully synthesized from low-cost and environmentally friendly materials. Adsorption is considered an efficient treatment technique for the removal of both toxic elements and pathogens by utilizing different adsorbents. For example, the nanostructures of $\mathrm{MgO}$ with a BET surface area of up to $171 \mathrm{~m}^{2} / \mathrm{g}$ obtained a very high adsorption capacity of $29,131 \mathrm{mg} / \mathrm{g}$ for fluoride ions in water, while the incorporation of iron in activated carbon has improved its adsorption capacity to $51.3 \mathrm{mg} / \mathrm{g}$ for arsenic. Moreover, certain adsorbents have shown the capability to remove $99 \%$ of the rotavirus and adenovirus from groundwater.

Summary Groundwater resources are contaminated with toxic metals and pathogens. Therefore, water treatment technologies should be evaluated for their efficiency to remove such contaminants. Determination of the most cost-effective and efficient treatment technique is not an easy task and requires the understanding of various aspects such as the contaminants present in water, the reuse options considered, and cost analysis of the treatment technique.
\end{abstract}

Keywords Groundwater $\cdot$ Toxic elements $\cdot$ Pathogens $\cdot$ Metals $\cdot$ Low-cost treatment techniques

\section{Introduction}

Throughout humankind's history, groundwater has been a highly crucial natural resource of fresh water, making $30 \%$ of global freshwater [1]. A significant freshwater percentage is supplied by groundwater to around 2 billion people, making around $40 \%$ of the irrigation water worldwide, as well as

This article is part of the Topical Collection on Water Pollution

Mohammad A. Al-Ghouti

mohammad.alghouti@qu.edu.qa

1 Department of Biological and Environmental Sciences, College of Arts and Sciences, Qatar University, P.O. Box 2713, Doha, Qatar

2 Department of Chemical Engineering, College of Engineering, Qatar University, P.O. Box 2713, Doha, Qatar

3 Department of Chemistry and Earth Sciences, College of Arts and Sciences, Qatar University, P.O. Box 2713, Doha, Qatar making about $50 \%$ of the world's municipal water [2]. Consequently, groundwater is currently under threat. Natural elements are present at higher levels in groundwater than in surface water due to the movement of groundwater throughout soil formations and rocks, dissolving various minerals and compounds [3•]. Overexploitation and unsustainable use of water especially in the Middle East and North Africa regions have caused groundwater depletion in the region (Table 1) [4], and what is left and available is contaminated which could be unsafe for human consumption or unfit for other purposes. Although utilization and degradation of groundwater quality have had significant attention around the world, a dramatic panorama has been generated from the poor management of water resources. By 2025, two-thirds of the population worldwide may live in water shortages $[5 \bullet, 6]$. The contaminations from both natural and anthropogenic sources further threaten their availability [7]. 
The types of natural contaminants and their concentrations depend on the geological nature of the materials, through which the groundwater flows, as well as the recharge water quality. The movement of groundwater through soils and sedimentary rocks can result in the release of a wide variety of contaminants, which affect the quality of water [8]. Since groundwater is a highly complex system with the interference of various variables and processes, understanding the relationships between groundwater, land-use, and contamination needs an advanced assessment tool. According to Verma et al. [9], the quality of groundwater depends on several different essential features, for example, natural or geo-genic factors such as native geomorphology and type of the sediment and minerals as well as the anthropogenic conditions including patterns of land-use. Microbial contaminants from animal and human waste could be another contamination source that can spread bacteria and parasites like microscopic worms and protozoa, as well as viruses [8]. Because of the complicated systems of groundwater and the change in its quality, a worldwide concern about groundwater quality is growing due to the importance of water in life. Thus, treatment of groundwater is highly significant, as, to sustain the social and economic development, water resources with high quality are considered very crucial factors [10].

Table 2 summarizes the presence of toxic metals and other elements in groundwater in different regions of the world. It is clear from Table 2 that the presence of these metals and chemical contaminants is a serious threat to the global groundwater resources. In comparison to the WHO (2017) [11] and USEPA (2018) [12] standards, several countries have reported higher concentrations of metals than the permissible limits. For example, the maximum concentration of boron was found to be $49.3 \mathrm{mg} / \mathrm{L}$ (mean value: $2.434 \mathrm{mg} / \mathrm{L}$ ) in Saudi Arabia [13•] and $3.819 \mathrm{mg} / \mathrm{L}$ (mean: $1.885 \mathrm{mg} / \mathrm{L}$ ) in Qatar [14••], much higher than the permissible limit of $2.4 \mathrm{mg} / \mathrm{L}$ (Table 2). Similarly, the concentration of lead in groundwater of Bangladesh [15••], China [16], Nigeria [17], and Pakistan [18•] is several orders of magnitude higher than the permissible limits (Table 2). This shows that the contamination of groundwater with these metals requires global attention.

Many researchers have also shown the contamination of groundwater with pathogenic microorganisms (bacteria, viruses, and protozoa) (Table 3). The presence of these bacteria such as V. cholera and Salmonella and viruses like hepatitis A virus, rotavirus, and adenovirus in water shows the potential of groundwater to cause various disease outbreaks in the exposed population.

Various treatment technologies have been used for the treatment of groundwater comprising physical, chemical, and biological technologies with different success rates. Physical treatments of groundwater include volatilization, ultrafiltration or filtration, incineration, and adsorption. Chemical techniques include precipitation, redox reactions, 
Table 2 Concentration of heavy metals and other elements in groundwater reported worldwide in comparison with the WHO and USEPA standards

\begin{tabular}{|c|c|c|c|c|c|c|c|c|c|c|c|}
\hline $\begin{array}{l}\text { Elements } \\
(\mu \mathrm{g} / \mathrm{L})\end{array}$ & $\begin{array}{l}\text { Bangladesh } \\
\text { (Dhaka) } \\
{[15]}\end{array}$ & $\begin{array}{l}\text { China } \\
\text { (Dongting } \\
\text { Lake plain) } \\
{[16]}\end{array}$ & $\begin{array}{l}\text { China } \\
\text { (Guanzhong } \\
\text { Plain) [19] }\end{array}$ & $\begin{array}{l}\text { India } \\
\text { (Tamil } \\
\text { Nadu) } \\
{[20]}\end{array}$ & $\begin{array}{l}\text { Iran } \\
\text { (Southeastern) } \\
{[21]}\end{array}$ & $\begin{array}{l}\text { Nigeria } \\
\text { (Ogun) } \\
{[17]}\end{array}$ & $\begin{array}{l}\text { Pakistan } \\
\text { (Northern) } \\
{[18]}\end{array}$ & $\begin{array}{l}\text { Qatar } \\
{[14 \bullet \bullet]}\end{array}$ & $\begin{array}{l}\text { Saudi } \\
\text { (Red Sea } \\
\text { coast) } \\
{[13 \bullet]}\end{array}$ & $\begin{array}{l}\text { WHO } \\
2017 \\
{[11]}\end{array}$ & $\begin{array}{l}\text { USEPA } \\
2018 \\
{[12]}\end{array}$ \\
\hline Arsenic & 2 & 7.4 & 1.095 & - & 15.5 & - & - & 2 & 4 & 10 & 10 \\
\hline Aluminum & - & 540.25 & 1.625 & - & - & - & - & 1.5 & - & 200 & 200 \\
\hline Boron & - & - & - & - & - & - & - & 1885 & 2434 & 2400 & 6000 \\
\hline Copper & 9.6 & 1.7 & 1.88 & 40 & 0.65 & 36 & - & 1.37 & 7.69 & 2000 & 1300 \\
\hline Cobalt & - & 0.03 & 0.165 & - & - & - & 171 & - & - & - & - \\
\hline Chromium & 1.5 & 21 & 21.535 & 30 & 8.75 & 16 & 89 & 3.912 & 1.27 & 50 & 100 \\
\hline Cadmium & - & 0.3 & 0.03 & - & - & 10 & 59 & - & 0.16 & 3 & 5 \\
\hline Fluoride & - & - & - & - & - & - & - & 3.81 & - & 1500 & 4000 \\
\hline Iron & 89.6 & 1076.5 & 28.005 & 260 & 8 & 708.5 & 1468 & 4.72 & - & - & 300 \\
\hline Lithium & - & - & - & - & - & - & - & 0.1206 & - & - & - \\
\hline Manganese & 58.8 & 434.5 & 10.32 & - & 1.32 & 156 & 627 & 1.009 & - & 400 & 30 \\
\hline Molybdenum & - & 0.4 & 6.28 & - & - & - & - & 53.88 & - & 70 & 40 \\
\hline Nickel & - & 0.32 & 0.945 & - & 7.23 & 82 & 92 & 1.94 & 25.62 & 20 & 100 \\
\hline Selenium & - & - & - & - & 4.3 & - & - & 8.882 & 86.58 & 40 & 50 \\
\hline Lead & 49.6 & 9.1 & 0.195 & - & - & 449.5 & 55 & - & 7.11 & 10 & 1.5 \\
\hline Vanadium & - & - & 4.07 & - & - & - & - & 14.36 & - & - & - \\
\hline Zinc & 5.3 & 1025.5 & 213.91 & 30 & 1.83 & 137.5 & 3738 & 5.88 & 57.9 & 3000 & 5000 \\
\hline Phosphates & 60 & - & - & - & - & - & - & - & 0.01 & - & - \\
\hline Sulfates & 11230 & - & - & - & 487 & - & - & 4977.2 & 1138.24 & 250000 & 250000 \\
\hline Nitrates & - & - & - & - & 13.7 & - & - & 36.32 & 22.64 & 50000 & 10000 \\
\hline
\end{tabular}

or ion exchange, while biological treatment can be carried out by using bioreactors or in slurry phase systems [29]. The technologies that are commonly used in the treatment of groundwater either have high treatment costs, produce harmful by-products, or energy-intensive [30, 31]. For instance, the ion exchange technique is a promising technique for the treatment of water with no generation of sludge, but this process is limited to specific pollutants as well as requires high cost for the replacement of the resin over time. Although the membrane filtration process is efficient in water treatment and can have high removal capacities without the generation of secondary pollution, its high manufacturing costs, severe fouling, and highenergy consumption are major drawbacks that limit its application. Therefore, much research is focusing on the use of more economic and environmentally friendly sustainable treatment techniques [32].

Based on our knowledge, there is no review paper that discusses the low-cost treatment techniques used for the simultaneous removal of chemical and microbial contaminants from groundwater. Therefore, this paper reviews the costefficient treatment techniques and the removal mechanisms of certain contaminants by the techniques, as well as the challenges and cost analysis of groundwater treatment.

\section{Simultaneous Removal of Toxic Elements from Groundwater Using Low-Cost Treatment Techniques}

The presence of certain elements such as fluoride, and heavy metals like arsenic, boron, and lead in groundwater is a major concern for environmental and public health. The groundwater contaminated from such elements, when used for irrigation and drinking purposes, may lead to toxic impacts on plants, animals, and humans. Therefore, the removal of such elements from groundwater should be considered before its application. There are various chemical, physical, and biological techniques that have been proved to be cost-effective and highly efficient in the treatment and simultaneous removal of multielements and microorganisms from groundwater. Among these techniques, adsorption, permeable reactive barrier, membrane distillation, electrocoagulation, and biological remediation will be discussed in detail.

\section{Treatment of Groundwater by Adsorption}

Adsorption is considered the best treatment technique for the removal of contaminants from water due to its higher removal 


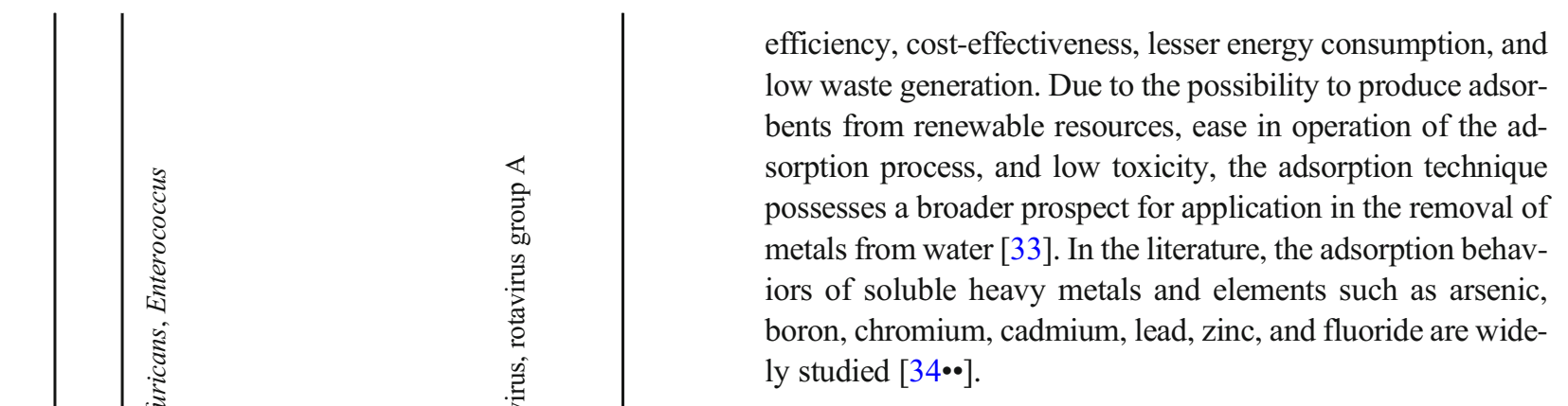

\section{Removal of Arsenic}

The presence of arsenic in groundwater is of great concern as it can cause toxicity even at a very low concentration of $<100$ $\mu \mathrm{g} / \mathrm{L}$. Moreover, the removal of arsenic is a must if the concentration is higher than $10 \mu \mathrm{g} / \mathrm{L}$ in water intended for drinking purposes [35]. Arsenic contamination in groundwater can occur from both natural and anthropogenic sources. The natural sources may include ferrous rocks, iron-pyrites, and resulting sediments. The most commonly found arseniccontaining mineral is arsenopyrite, desorption of which releases arsenic into the groundwater. On the other hand, the anthropogenic sources include industrial and domestic waste, agricultural and mining activities, leachates from landfills, and burning of coal [36]. Arsenic commonly exists in two forms, i.e., arsenite $(\mathrm{As}(\mathrm{III}))$ and arsenate $(\mathrm{As}(\mathrm{V}))$. Arsenite is considered more toxic due to its water solubility than the organic/ inorganic form of arsenate [35].

The adsorbents derived from natural sources such as eggshell, tea waste, and pomegranate peels among others have been successfully utilized for the removal of arsenic from water. Maity et al. [37] demonstrated a comparative assessment on the removal of arsenic from groundwater by natural magnetic material (NMM) (rock) and synthesized magnetic material (SMM) by humic acid and Bacillus pasteurii. Results showed that, within 120 min, both NMM and SMM were able to achieve arsenic removal efficiency in the range of 90 to $100 \%$, but it was observed that NMM exhibited very fast arsenic removal, as it was capable to remove up to $87 \%$ within $30 \mathrm{~s}$. Therefore, easy removal of arsenic can be achieved by utilizing NMM and because of the particle's magnetic properties; the adsorbent can be separated from arsenic-free water after the arsenic removal. The obtained results indicated the applicability of the eco-friendly and cost-effective NMM green material for the treatment of arsenic-contaminated groundwater.

In the literature, various adsorbents (iron-containing compounds, activated carbon, and fly ash) have been reported to achieve a high adsorption capacity of $150 \mathrm{mg} / \mathrm{g}$ [35]. The loading of iron into the adsorbents has helped to improve the adsorption capacity for arsenic as a result of co-precipitation mechanisms. Figure 1 shows various iron-based adsorbents 
Fig. 1 Adsorption capacity of iron-based adsorbents tested for the removal of arsenic from water [40-49]

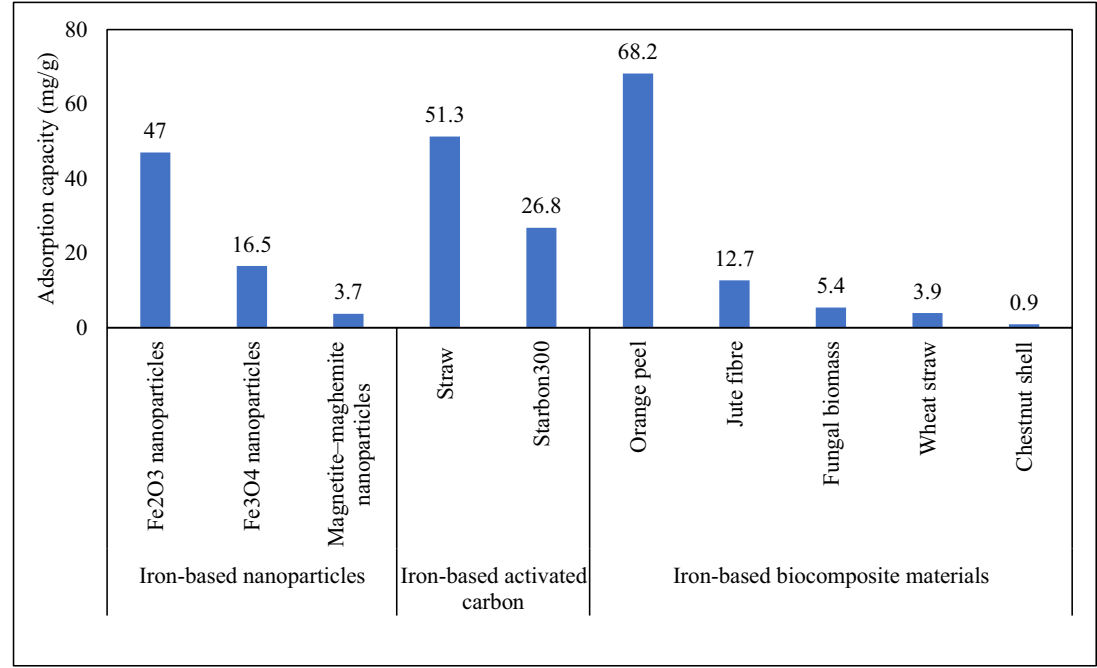

(activated carbon, biocomposites, and nanoparticles) that have shown to have an affinity towards adsorption of arsenic, As(III). Similar results have also been reported for As(V). For example, the use of activated carbon achieved 55\% removal of $\mathrm{As}(\mathrm{V})$, while, the loading of iron onto the activated carbon improved the \% removal up to $97 \%$ [38]. Callegari et al. [39] investigated the simultaneous removal of both $\mathrm{As}(\mathrm{V})$ and $\mathrm{As}(\mathrm{III})$ from groundwater. In this study, an iron oxide-coated sand column filter was utilized for the removal process where the experimental tests gave satisfactory results with removal rates that reached $99 \%$.

\section{Removal of Boron}

Boron is a commonly found contaminant in both seawater and groundwater, where its concentration varies from 0.3 to 100 $\mathrm{mg} / \mathrm{L}$ in groundwater. Boron exists as part of compounds since elemental boron has not been found yet. It is commonly used in many industries such as the glass industry, pharmaceutical industry, and cosmetics industry. According to the WHO, the concentration limit for boron is $2.4 \mathrm{mg} / \mathrm{L}[50 \bullet \cdot$.

Various types of adsorbents (activated carbon, chelating resins, fly ash, and those derived from natural sources) can be used to separate boron from water even at very low concentrations. Table 4 provides a summary of adsorption capabilities, experimental conditions, and isotherm models for some selected adsorbents. Chen et al. [51] used magnetic magnetite nanoparticles (MMN) as an adsorbent to remove boron. The MM nanoparticles were synthesized by facile coprecipitated method with super magnetism and high specific surface area. It was found that the adsorption was endothermic, spontaneous chemisorption process, which was dominated by the external film diffusion and entropy change instead of the enthalpy change. Furthermore, adsorption equilibrium was rapid as it was achieved within $1.5 \mathrm{~h}$ with approximately 50 $\mathrm{mg} / \mathrm{g}$ equilibrium capacity at $\mathrm{pH} 7$ and $45^{\circ} \mathrm{C}$. The $\mathrm{MNN}$ is found to be a promising agent for the removal of boron as it has low cost and easy regeneration and can be separated by an external magnetic field, as well as having satisfactory mechanical strength.

\section{Removal of Fluoride}

The contamination of fluoride in groundwater is considered one of the most significant problems in the world. Fluoride exists in a variety of forms which include fluorite $\left(\mathrm{CaF}_{2}\right)$, cryolite $\left(\mathrm{Na}_{3} \mathrm{AlF}_{6}\right)$, and fluorapatite $\left(\mathrm{Ca}_{5}\left(\mathrm{PO}_{4}\right)_{3} \mathrm{~F}\right)$, and release of fluoride occurs as a result of its dissolution in groundwater under variable chemical conditions. The concentration of fluoride exceeding $1.5 \mathrm{mg} / \mathrm{L}$ can be harmful to humans, as per the WHO recommendation [60].

Adsorption techniques using a variety of adsorbents including nanomaterials, metal composites, and adsorbents derived from organic sources have been used for the defluoridation of water (Table 5). For example, the pristine and magnetic biochar by peanut hull and bovine bone was synthesized for the adsorption of fluoride from groundwater [61]. The results showed that higher adsorption capacity was achieved when preparing magnetic biochar by soaking in $\mathrm{FeCl}_{3}$ solution and then pyrolyzing compared to when mixing pristine biochar with a $\mathrm{Fe}^{2+} / \mathrm{Fe}^{3+}$ solution and then treating with $\mathrm{NaOH}$. The high adsorption capacity of fluoride by both bone-derived biochar and magnetic biochar can be attributed to the presence of $\gamma-\mathrm{Fe}_{2} \mathrm{O}_{3}$ and hydroxyapatite (HAP) that formed during the charring bones. Similarly, Pigatto et al. [62] also developed an environmentally friendly and cost-efficient technique for the removal of fluoride from groundwater, namely adsorption onto calcinated sludge. The results showed that, under the optimum experimental conditions of $5 \mathrm{~g} / \mathrm{L}$ as adsorbent dosage and a $\mathrm{pH}$ of 5.5, the maximum adsorption capacity was more 
than $70 \%$, which was enough to attain the WHO limits of 1.5 $\mathrm{mg} / \mathrm{L}$. The WHO limit was achieved within $60 \mathrm{~min}$. Thus, these results indicated the ability to use calcinated sludge as an environmentally friendly and low-cost adsorbent for the treatment of groundwater.

In addition, Ayinde et al. [63・•] synthesized a multifunctional 3-layered $\mathrm{Ag}-\mathrm{MgO} /$ nanohydroxyapatite (Ag$\mathrm{MgOnHaP}$ ) composite for the removal of fluoride and bacteria from groundwater. Citrus paradisi peel extract was used for the reduction of $\mathrm{Ag}$ and $\mathrm{MgO}$ ions and impregnation of $\mathrm{Ag}$ $\mathrm{MgO}$ nanoparticles on the surface of the adsorbent. Results showed that $90 \%$ fluoride removal was achieved by using the synthesized adsorbent. The best-fit isotherm model for the experimental adsorption data was the Freundlich isotherm model indicating that adsorption happened on a multilayered heterogeneous surface. Table 5 summarizes the highest adsorption capacities $(\mathrm{mg} / \mathrm{g})$ obtained for fluoride and reported in the literature at variable concentrations, contact time, and $\mathrm{pH}$.

\section{Removal of Multiple Toxic Elements from Groundwater}

Besides arsenic, boron, and fluoride, there are many other elements and toxic metals that have been reported in the literature (Table 2). Some researchers have also attempted to develop novel low-cost adsorbents for the simultaneous removal of these elements from groundwater. For example, ArancibiaMiranda et al. [92••] investigated the synthesis of iron oxidefunctionalized magnetic imogolite nanocomposite for the simultaneous removal of copper, cadmium, and arsenic from groundwater. The physicochemical properties for the prepared nanocomposite showed that the size and distribution of the magnetite nanoparticles were mainly dependent on the concentration of $\mathrm{Fe}^{3+}$ rather than the presence of aluminosilicate in which a higher concentration of $\mathrm{Fe}^{3+}$ favored the 3dimensional growth of Fe-oxides with multilayer formation. The isotherm studies showed that there were at least 4 kinds of adsorption sites that held variable metal selectivity, namely preferential copper sites, preferential cadmium sites, arsenate preferential sites, and non-preferential sites for copper, cadmium, or arsenate. Moreover, this study compared the use of adsorbent in multi-component systems and a singlecomponent system and found that a $12 \%$ decrease in adsorption of copper by imogolite resulted in a multi-component system as compared to the single-component system, while cadmium exceeded $41 \%$ in the same case. This could be attributed to the chemical characteristics of the adsorbate in the affinity of these metal ions towards $\equiv \mathrm{Al}-\mathrm{OH}$ and $\equiv \mathrm{Si}-\mathrm{OH}$ groups conditioned by their ionic radius, polarizability, and electronegativity. Similar behavior was observed when the synthesized nanocomposite was used, but a slight decrease 


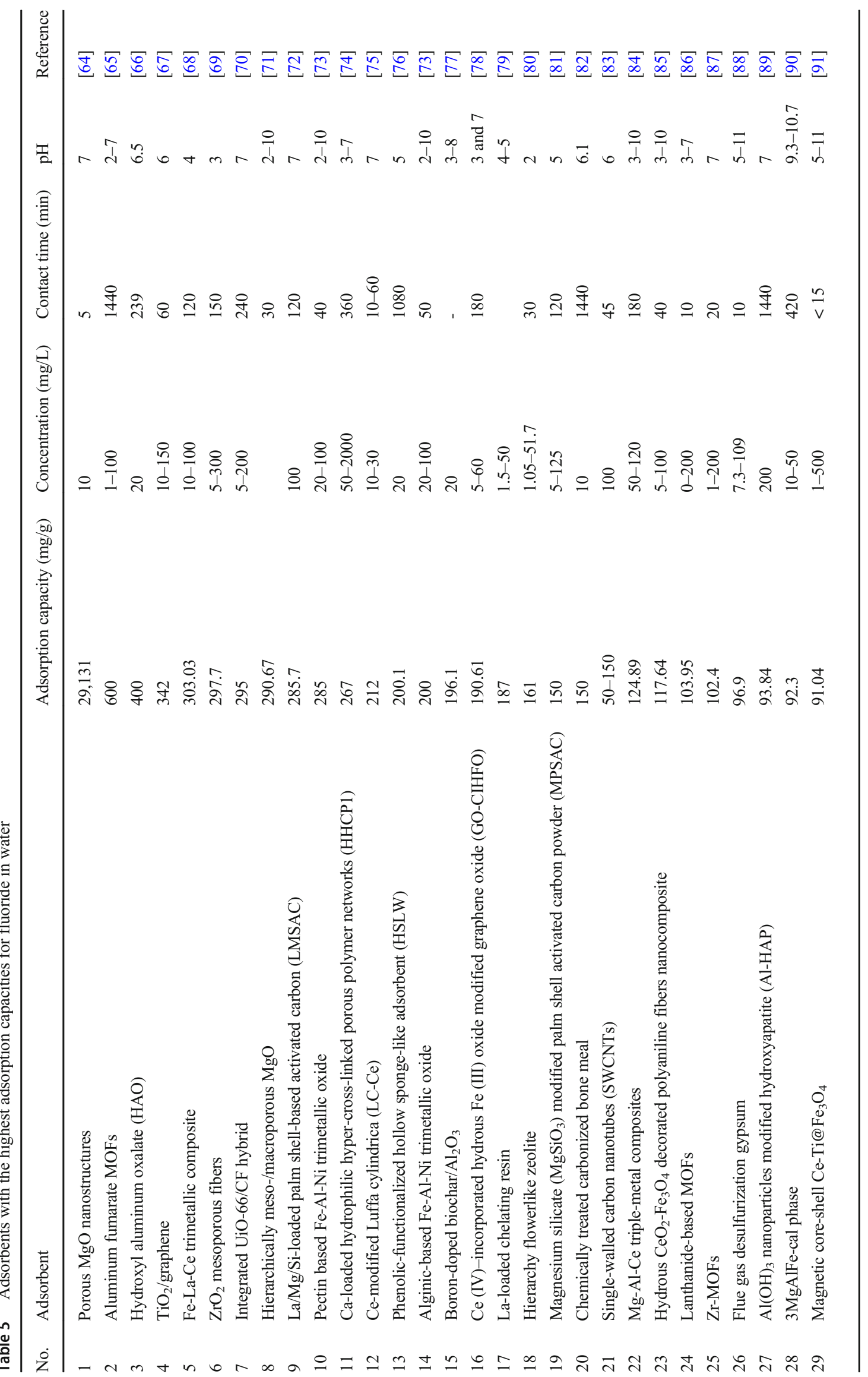


in cadmium adsorption difference between the single- and multi-component systems due to the electrostatic effects and changes in nanocomposite porosity, as well as the presence of $\equiv \mathrm{Fe}-\mathrm{OH}$ groups. Furthermore, arsenate presence in the system favored the divalent metal removal such as copper and cadmium in which its existence modified the selectivity and affinity of the original active sites of both the imogolite and the synthesized nanocomposite. This could lead to a reduction in the common sites' density of copper and cadmium. However, it generates specific sites for each metal affecting the adsorption macroscopic behavior.

Besides, Khalfa et al. [93] evaluated the efficiency of natural and activated clay for the simultaneous removal of lead, copper, zinc, and cadmium from groundwater. An affinity order of $\mathrm{Pd}^{2+}>\mathrm{Cu}^{2+}>\mathrm{Zn}^{2+}>\mathrm{Cd}^{2+}$ was obtained from the adsorption experiments results. The preferential lead removal over other metals could be due to the effect of metal physicochemical properties on the removal mechanism such as electronegativity, atomic radius, constant hydrolysis, and relative binding strength.

Bortone et al. [94] combined the use of advanced drainage systems with adsorption termed as in situ reactive drainage systems for groundwater treatment (In-DRAIN-TREAT). This process took into consideration the natural gradient of groundwater for the passive treatment process in which a drainage system was used for collecting the contaminated groundwater by means of horizontal drains that are located longitudinally to the flow direction, which in turn directs it to a waterproofed cell. This was directly treated into an active cell that is located downstream to avoid any external energy inputs. This study compared the use of this innovative treatment system with a permeable reactive barrier technology for the removal of hexavalent chromium. Their preliminary results showed that the use of treatment cells filled with activated carbon and with no energy consumption was applicable and efficient in the treatment process as it showed a $10 \%$ reduction in the remediation costs.

Abraham et al. [95] explored the removal of $\mathrm{Fe}(\mathrm{II})$ from groundwater by using ferric hydroxide $\left[\mathrm{Fe}(\mathrm{OH})_{3}\right]$ flocs as media for the adsorptive removal process. In this study, $\mathrm{Fe}(\mathrm{II})$ is directly adsorbed on $\mathrm{Fe}(\mathrm{OH})_{3}$ precipitate, as it is converted to $\mathrm{Fe}$ (III) and subsequently the hydrolysis of $\mathrm{Fe}(\mathrm{OH})_{3}$ causing the formation of a new surface for further adsorption. Therefore, the frequent replacement or maintaining of the media was not required as well as the un-needed backwashing process, which in turn makes this method more cost-effective. Results indicated that this method was significantly efficient in removing $\mathrm{Fe}$ (II) from groundwater. However, the presence of competitive ions such as $\mathrm{Ca}^{2+}$ and $\mathrm{Mn}^{2+}$ can reduce the adsorption efficiency while ions such as $\mathrm{SO}_{4}{ }^{2-}, \mathrm{Cl}^{-}$, and $\mathrm{F}^{-}$had no significant competitive effect on the adsorption process. Moreover, Elkady et al. [96] synthesized a magnetic hybrid adsorbent matrix for the simultaneous adsorption of iron and manganese ions from groundwater. In this study, magnetic hydroxyapatite (HAP) nanocomposites were synthesized by co-precipitation and microwave method; two adsorbents were prepared, namely HAP and advanced magnetic hydroxyapatite (MHAP). The results indicated superior adsorption behavior of MHAP toward both iron and manganese ions with removal efficiencies of $98 \%$ and $95 \%$, respectively, while HAP achieved $86 \%$ and $80 \%$ for the removal of both iron and manganese, respectively.

For the efficient removal of lead, cadmium, and zinc from groundwater, Holmes et al. [97] explored the incorporation of lime softening wastes as recycled drinking water treatment wastes (DWTW), and low-cost additive to replace the ordinary Portland cement (OPC) with cement-based filter media (CBFM). The results showed $100 \%$ removal of the three heavy metals from groundwater by the novel adsorbent at low concentrations of DWTW $(0.01 \mathrm{mM})$; however, increasing the concentration of DWTW $(1.00 \mathrm{mM})$ leads to a decrease in the removal efficiency. This could be attributed to either the saturation or the exhaustion removal mechanism. It is illustrated from the study that DWTW has the potential to be used as an enhancement for CBFM as this incorporation has a large sequestration capacity to lead, cadmium, and zinc through insoluble carbonate formation.

It is strongly indicated from the obtained results that the used adsorbents were successfully synthesized from low-cost and environmentally friendly materials. To conclude, adsorption is considered an efficient treatment technique for the removal of various contaminants from groundwater by utilizing different adsorbents. However, prior to the implementation of the adsorption process for the treatment of groundwater, the cost of adsorbent regeneration should be considered, as some regeneration processes are energy-intensive and costly. In such cases, other treatment options should be investigated such as biological treatment techniques. Although the applicability and efficiency of the adsorption technique on the treatment and removal of different contaminants from groundwater are proved, this technique is unable to continuously produce potable water with high quality because it is limited in the simultaneous removal of contaminants especially those present in saline groundwater. Hence, the application of membrane techniques as a post-treatment technique must be considered for such cases.

\section{Treatment of Groundwater by Permeable Reactive Barrier}

Permeable reactive barriers (PRBs) are widely implemented, cost-effective, and viable technology where contaminated groundwater flow is not restricted as it passes over the reactive fluid, i.e., barrier material, for the immobilization or passive contaminant degradation. A variety of materials can be used 
as reactive materials for groundwater treatment such as zerovalent iron, limestone, microorganisms, straw, peat, and various other materials [98]. According to Zhang et al. [99], a PRB enables the contact of the contaminated groundwater with the adsorptive material, which is inserted underground in a natural aquifer in which the contaminants are removed by intercepting the pollution plume and without water pumping. Therefore, this valuable innovative technology is considered cost-effective, environmentally friendly, and more economical over the long term when compared with other techniques that require energy input continuously.

Falciglia et al. [100] investigated the potential use of a novel microwave-based regenerating permeable reactive barrier (MW-PRB) system for the removal of cesium (Cs) from groundwater with the use of activated carbon as an adsorbent in both batch experiments and column MW-regeneration experiments. The results showed that $80 \%$ removal of Cs was achieved with the column experiments when activated carbon was irradiated for $15 \mathrm{~min}$. Moreover, it was revealed by the techno-economic analysis that this technique is feasible and advantageous compared to the conventional PRB system as the saved cost confirms the costeffectiveness of the MW-PRB system encouraging the implementation of this technique.

Maamoun et al. [101] investigated the use of PRB for the removal of $\mathrm{Cr}(\mathrm{VI})$ from groundwater by using 4 reactive materials, namely nanoscale zerovalent iron $\left(\mathrm{Fe}^{\circ}\right)$, bimetallic nanoscale zerovalent iron $\left(\mathrm{Fe}^{\circ} / \mathrm{Cu}\right)$, activated carbon, and sand/zeolite mixture. Results showed the superiority of $\mathrm{Fe}^{\circ}$ over other reactive materials with a $\mathrm{Cr}(\mathrm{VI})$ removal efficiency of $89.7 \%$. Meanwhile, $\mathrm{Fe}^{\circ} / \mathrm{Cu}$, activated carbon, and the sand/zeolite mixture had a removal efficiency of $84.1 \%$, $23.01 \%$, and $14.0 \%$, respectively. Faisal et al. [102] converted inert sand into a reactive material by coating the surface with humic acid nanoparticles that were extracted from sewage sludge. The coated sand-humic acid (CSHA) ability for the simultaneous removal of copper and cadmium from groundwater was investigated. Results showed that CSHA had a maximum adsorption capacity of $87.5 \mathrm{mg} / \mathrm{g}$ for copper and $18.9 \mathrm{mg} / \mathrm{g}$ of cadmium with removal efficiencies of more than $98 \%$. Moreover, the results indicated that the predominant mechanism for the treatment process was the physisorption process.

Wen et al. [103] suggested the use of raw straw agricultural waste as a potential PRB carbon source because of its high content of elemental carbon. In this study, straw zerovalent iron and zerovalent iron-free sustainable-release carboncompound material (ZVI-free SCCM) were used as field PRB fillers to determine their ability in reducing nitrogen transport from shallow groundwater to surface water. Results indicated the potential efficiency of the used filler to remove nitrogen as well as avoid the problem of secondary pollution, such as high ammonium nitrogen concentration in the treated groundwater. The results showed that more than $60 \%$ of nitrogen was removed from groundwater; therefore, straw waste can be a sustainable filler matrix alternative to the widely used wood chips in the PRB system.

The use of a granular mixture of ZVI and lapillus at different weight ratios (30:70 and 50:50) as a reactive media in PRB through column experiments was tested [104]. Higher iron content (50:50) of the ZVI/lapillus mixture had a higher reduction of the hydraulic conductivity over time but had higher removal rates. Results represented the efficiency of the two used reactive media in removing the studied pollutants according to the following sequence: $\mathrm{Cu}>\mathrm{Zn}>\mathrm{Ni}$. This removal behavior could be attributed to the affinity of iron oxides and hydroxides towards the 3 contaminants. Different removal mechanisms were responsible for the removal process. The removal of copper from contaminated groundwater could be due to the cementation process that occurred at the surface of ZVI when iron (hydro)oxide was not covering it which in turn prevented the electron transfer. Moreover, quantitative removal of nickel, zinc, and copper could be due to the precipitation mechanisms as they can precipitate as hydroxides when the $\mathrm{pH}$ of the flowing water through ZVI increases, or by adsorption onto the surface of (hydro)oxide, or by the coprecipitation with iron hydroxides.

Permeable reactive barrier treatment techniques can treat groundwater in biological, physical, or chemical processes. This treatment technique is effective for contaminants that are not deeper than $20 \mathrm{~m}$ beneath the ground surface and it might require the replacement or removal of the reactive media during operation. Moreover, the effectiveness of this treatment technique depends on the $\mathrm{pH}$ range of the barrier chemical which should be selected based on the used sorbent and the metal removed. This could be a limiting factor when removing multiple contaminants at the same time. Furthermore, zerovalent iron is the most used reactive material; however, the production of this material is energy-intensive leading to an increase in the environmental effects of the permeable reactive barrier process. In addition, more research is recommended to be carried out on the effect of $\mathrm{pH}$, temperature, and dissolved salts on the removal efficiency of this technique. Therefore, further research is required for the use of low-cost natural products as reactive materials for the simultaneous removal of multi-elements and microorganisms from groundwater by a permeable reactive barrier.

\section{Treatment of Groundwater by Membrane Distillation}

The membrane distillation (MD) process is thermally driven where water vapor molecules pass through a porous hydrophobic membrane. This process is enhanced by inducing the vapor pressure by the difference in temperature across the membrane, 
which in turn reaches solution saturation without a significant decline in the flux [105]. Moreover, this technique utilizes lowgrade energy for operation, which can be generated by wastegrade energy, solar energy, or geothermal energy. Thus, it is considered an efficient and cost-effective alternative treatment process when compared to other conventional membrane processes [106]. Synthesis of MD membranes occurs by using different methods such as phase inversion and electrospinning techniques by using hydrophobic polymers like polyvinylidene fluoride (PVDF), polypropylene (PP), polyethylene (PE), or polytetrafluoroethylene (PTFE). Modification with nanoscale materials such as silver, silica, and titania as well as graphene and carbon nanotubes (CNTs) significantly enhances the performance of the MD membranes and its hydrophobicity, prevents wetting and fouling, and improves the membrane mechanical strength. Various methodologies can be used for modifying the MD membranes, namely dip coating, graft polymerization, and interfacial polymerization [107].

Mishra et al. [108] synthesized and introduced ferrous sulfide (FeS) and carboxyl-functionalized ferroferric oxide (CFFO) nanoparticles into PVDF membrane through phase inversion technique and produced 3 membranes, namely FeS/PVDF, $\mathrm{CFFO} / \mathrm{PVDF}$, and FeS/CFFO/PVDF. In this study, the prepared membranes were examined for the simultaneous removal of lead, cadmium, and chromium from groundwater. Results showed that the synthesized membranes had enhanced porosity, good mechanical and thermal stability, high water flux, and high water uptake capacity, as well as high efficiency in the removal of the three tested pollutants. Furthermore, among the three prepared membranes, FeS/CFFO/PVDF membrane showed the highest efficiency for the simultaneous removal of lead, cadmium, and chromium from real groundwater with a removal percentage of $98.7 \%, 96.4 \%$, and $95.4 \%$, respectively. In addition, the developed membrane was able to remove total arsenic from the tested real groundwater with an excellent removal efficiency of $95.9 \%$.

Moreover, low-cost hydrophobic kaolin hollow fiber membranes (h-KHFM) were used through phase inversion/ sintering technique [109], and then it was followed by grafting with fluoroalkylsilane (FAS) molecules as a modification in which its ability for the simultaneous removal of arsenite and arsenate was investigated through direct contact membrane distillation (DCMD) system. Results showed that the wettability and strength properties of the membrane were enhanced by hydrophobization of KHFM into h-KHFM. Moreover, it has been revealed from the obtained results that preparing $h-$ KHFM at a sintering temperature of $1300{ }^{\circ} \mathrm{C}$ induced an excellent liquid entry pressure (LEPw) value of 2 bar and high contact angle value of $145^{\circ}$ as well as $0.32 \mu \mathrm{m}$ average pore size. Consequently, at a feed temperature of $60{ }^{\circ} \mathrm{C}$, the required standard of maximum contaminant level of arsenic was met, with $100 \%$ removal of both arsenite and arsenate with high permeate flux of $28 \mathrm{~kg} / \mathrm{m}^{2} \mathrm{~h}$ and 25 $\mathrm{kg} / \mathrm{m}^{2} \mathrm{~h}$, respectively.
Manna and Pal [110] investigated arsenic removal from groundwater by utilizing solar energy for phase change in a new flash vaporization membrane distillation (FVMD) module, which was fitted with a composite flat-sheet PTFE membrane. This technique has more process safety and lower equipment cost when compared to nanofiltration and reverse osmosis as well as electrodialysis. Monitoring of both the membrane flux and rejection of arsenic has been done during variation of different parameters including feed temperature, distillate temperature, and velocity and the concentration of arsenic in the feed, as well as the operating hours. The results showed that, in all the investigated parameters, more than $99 \%$ rejection of arsenic with the highest flux of $52.94 \mathrm{~kg} / \mathrm{m}^{2} \mathrm{~h}$ was achieved with the cross-flow mode of the FVMD module working in the configuration of direct contact membrane distillation (DCMD). Moreover, it has been observed that membrane performance in terms of arsenic rejection and flux remained the same after $40 \mathrm{~h}$ of investigation. The obtained results indicate the applicability of the solar-powered FVMD system for the removal of arsenic from groundwater. However, based on our knowledge, this treatment technique is still applicable on a small scale, and more detailed research is required to apply it on a larger scale taking into consideration the water flux, cost, and time consumed. Therefore, other treatment techniques could be used such as biological treatment methods.

\section{Treatment of Groundwater by Electrocoagulation Method}

The electrocoagulation process involves the use of metal cation as a coagulant, while iron or aluminum is used as an anode in an electrochemical reaction. As a result of this reaction, the metal anode is oxidized, while metal cation is released into the solution. This metal cation then reacts to form metal hydroxides resulting in the agglomeration of pollutants. Overall, in an electrocoagulation system, metals are removed through oxidation, reduction, co-precipitation, and adsorption mechanisms [111]. Ullah et al. [112] mentioned that the remediation mechanism of groundwater by zerovalent iron (ZVI) depends on the standard redox potential $\left(E^{0}\right)$ as well as the metal ions' chemical speciation. Adsorption is used for remediation of metal contaminants with $E^{0}$ close to or more negative than that for $\mathrm{Fe}^{0}$, while metal contaminants with much more positive $E^{0}$ value than $\mathrm{Fe}^{0}$ are removed by surface-mediated reductive precipitation. On the other hand, both reduction and adsorption process could be used for the remediation of metallic cations such as $\mathrm{Pb}^{2+}$ and $\mathrm{Ni}^{2+}$ that are slightly more electropositive than $\mathrm{Fe}^{0}$. According to Guan et al. [113], since Fe oxide/hydroxide precipitation is a dynamic process, contaminants in groundwater are removed either by adsorption where they are adsorbed into the aged Fe oxyhydroxides or 
by precipitation where contaminants are adsorbed into the nascent $\mathrm{Fe}$ oxyhydroxides in which during aging they can be entrapped in their structure.

Maitlo et al. [114] investigated the use of iron-air fuel cell electrocoagulation (IAFCEC) system for the removal of chromium $(\mathrm{Cr}(\mathrm{VI}))$ from groundwater as an innovative and costeffective treatment technique. The obtained results from this study illustrated the ability of this treatment option to remove $100 \%$ of chromate in groundwater within $4 \mathrm{~h}$ and $0.2 \mathrm{USD} \mathrm{m}^{3}$ as operating cost. Since chromate is mobile in groundwater, it is suggested for the removal of chromate in electrocoagulation to have electrochemical oxidation of zerovalent iron to $\mathrm{Fe}$ (II) ions and reduction of $\mathrm{Cr}(\mathrm{VI})$ to $\mathrm{Cr}(\mathrm{III})$ ions at the surface of the anode and cathode electrodes, respectively. These reactions are usually accompanied by $\mathrm{Cr}(\mathrm{OH})_{3}$ and $\mathrm{Fe}(\mathrm{OH})_{3}$ coprecipitation inside the reactor. Moreover, the obtained results showed that the in situ production of stable iron hydroxides during IAFCEC operation leads to the co-precipitation of $\mathrm{Cr}(\mathrm{VI})$. It is evident from the merits of this system that it is less dependent on the initial $\mathrm{pH}$, supporting electrolyte concentration, treatment capacity, and operating time. Thus, the IAFCEC can be recommended as one of the best options for the removal and treatment of chromium. According to the literature, the chromium remediation mechanism through electrocoagulation can be described in two ways: firstly, chromate in an aqueous medium interacts with $\mathrm{Fr}(\mathrm{II})-$ and $\mathrm{Fe}(\mathrm{II})-$ bearing minerals such as biotite and magnetite which in turn causes the chromate reduction into chromite ions. Then, inside the reactor, co-precipitation of $\mathrm{Cr}(\mathrm{OH})_{3(\mathrm{~s})}$ and/or $(\mathrm{Fe}$, $\mathrm{Cr})(\mathrm{OH})_{3(\mathrm{~s})}$ takes place. Secondly, inner-sphere monodentate and bidentate complexes form on the surface of aqueous chromate ions $\left(\mathrm{HCrO}_{4}{ }^{-}\right.$and $\left.\mathrm{CrO}_{4}{ }^{2-}\right)$ and iron oxides after their interaction $[115,116]$.

Similarly, Amarine et al. [117] used electrocoagulation for the removal of nitrate and sulfate simultaneously from groundwater due to its simplicity, ease of operations, and cost-effectiveness as well as high efficiency (Table 6). The experiments were carried out in a batch cell with aluminum electrodes. Results showed that the removal efficiency for nitrate reached up to $94.1 \%$, while sulfate removal efficiency reached up to $97.86 \%$.

Figure 2 a describes the simultaneous removal of $\mathrm{Mn}^{2+}$, $\mathrm{Fe}^{2+}$, and antibiotics in groundwater using peroxymonosulfate (PMS)-assisted in situ oxidation/coagulation $(\mathrm{O} / \mathrm{C})$ coupled with ceramic membrane process [118]. Here, the ${ }^{\circ} \mathrm{OH}$ and $\mathrm{SO}_{4}{ }^{--}$will be generated in situ during the oxidation process through the activation of PMS by ferrous within groundwater, and precipitate ferric hydroxides or manganese during the coagulation process. Guo et al. [119] studied the simultaneous removal of $\mathrm{NH}_{4}{ }^{+}$and $\mathrm{Mn}^{2+}$ from groundwater using ironmanganese co-oxide filter film $(\mathrm{MeOx})$ as a catalyst. $\mathrm{NH}^{4+}$ was oxidized to $\mathrm{NO}^{3-}$ through the process of catalytic oxidation (Fig. 2b). Yang et al. [120] studied the simultaneous removal of $\mathrm{Cs}^{+}$and $\mathrm{Sr}^{2+}$ from groundwater using low-cost inorganic ion exchange materials such as sulfur-modified chabazite (CHA). It was concluded that the selectivity of $\mathrm{Cs}^{+}$was enhanced by the sulfur loading. This was due to the increase of the Lewis acid-base interaction between sulfur and $\mathrm{Cs}^{+}$. However, as the sulfur loading increased up to $5 \%$, there was a slight increase in the selectivity of $\mathrm{Sr}^{2+}$ and decreased subsequently (Fig. 2c).

\section{Treatment of Groundwater by Biological Treatment Methods}

Biological treatment refers to the use of microorganisms, algae, and fungi for the degradation/removal of pollutants from water under aerobic and anaerobic conditions. Biological agents remove pollutants in a variety of ways. The organic pollutants are removed through oxidation or incorporation into the living cells or through utilizing them as a source of carbon and energy [121], whereas some inorganic pollutants are removed through secondary mechanisms such as by the production of extracellular polymeric substances like polysaccharides and proteins. These substances are able to produce complexes with metal ions, thereby removing them from the aqueous medium [122]. Moreover, microorganisms have the capabilities to withstand the high toxicity of these metals and can also remediate these metals through a variety of metabolic processes resulting in oxidation and reduction of these metals [123]. Biological treatment techniques are cost-effective as they use microbial degradation, adsorption by microbial biomass (living or dead), and bioremediation technologies. Biological techniques are being utilized in conjunction with other techniques to improve the sustainability and costeffectiveness of these techniques. There are a variety of biological techniques that have been used for the removal of metals such as biological aerated filters (BAF), anaerobic suspended growth biological reactors, sequencing batch reactors (SBR), phytoremediation, anaerobic sequencing batch reactor (ASBR), and microbial fuel cells (MFCs).

Crognale et al. [124] evaluated the potential of treating arsenic-contaminated groundwater by biological As(III) oxidation in biofilters by establishing biofilms from native groundwater microorganisms. The $90 \%$ oxidation efficiencies were reached within $3 \mathrm{~h}$ with an initial arsenic concentration of 0.1 $\mathrm{mg} / \mathrm{L}$ by using coarse sand biofilters. Furthermore, detailed microbial characterization of As(III) oxidizing biofilms was carried out and indicated the presence of various OTUs affiliated with different families that are known for their oxidizing ability for As(III), namely Burkholderiaceae, Comamonadaceae, Rhodobacteraceae, and Xanthomonadaceae. To sum up, the obtained results indicate the high potential of the biological As(III) oxidation process in biofilters with filling material that has low cost and easily availability. Moreover, the native 
Table 6 Summary of the removal efficiencies of different removal techniques discussed in the paper for the removal of different contaminants from groundwater

\begin{tabular}{|c|c|c|c|c|}
\hline No. & Contaminant & Removal technique & $\begin{array}{l}\text { Removal } \\
\text { efficiency } \\
(\%)\end{array}$ & Reference \\
\hline \multirow[t]{4}{*}{1} & \multirow[t]{4}{*}{ Arsenic } & Solar-powered flash vaporization membrane distillation & 99.0 & {$[110]$} \\
\hline & & Iron oxide-coated sand column filter & 99.0 & [39] \\
\hline & & Natural/synthesized magnetic material by humic acid and Bacillus pasteurii & $90-100$ & {$[37]$} \\
\hline & & Biofilters & 90.0 & [124] \\
\hline 2 & Boron & Magnetic magnetite nanoparticles & 90.0 & {$[51]$} \\
\hline 3 & Cesium & Microwave-based regenerating permeable reactive barrier & 80.0 & {$[30]$} \\
\hline 4 & Chromium & Iron-air fuel cell electrocoagulation & 100.0 & {$[100]$} \\
\hline 5 & Chromium & Nanoscale zerovalent iron-permeable reactive barrier & 89.7 & {$[101]$} \\
\hline 6 & Copper and cadmium & Coated sand-humic acid & 98.0 & {$[102]$} \\
\hline \multirow[t]{2}{*}{7} & \multirow[t]{2}{*}{ Fluoride } & Calcinated sludge & 70.0 & {$[62]$} \\
\hline & & Multi-functional 3-layered $\mathrm{Ag}-\mathrm{MgO} /$ nanohydroxyapatite composite & 90.0 & {$[63 \bullet \bullet]$} \\
\hline 8 & Iron and manganese & Advanced magnetic hydroxyapatite nanocomposite & $95-98$ & [96] \\
\hline 9 & Lead & Moringa oleifera seeds and Musa cavendish peel & 81.0 & {$[130 \bullet]$} \\
\hline 10 & Lead, cadmium, zinc & Lime softening waste on cement-based filter media & 100.0 & [97] \\
\hline 11 & Nitrate and sulfate & Electrocoagulation & $94.1-97.86$ & {$[117]$} \\
\hline 12 & Nitrate, magnesium, phosphorus, and zinc & Scenedesmus sp. immobilized on alginate gel & $92-100$ & [133] \\
\hline 13 & Nitrogen & Raw straw-permeable reactive barrier & $>60$ & {$[103]$} \\
\hline 14 & Vanadium & Sawdust pine-carbon source for microbial removal & 82.60 & [135] \\
\hline
\end{tabular}

groundwater bacteria had the ability to tolerate high concentrations of arsenic and can easily form highly As(III) oxidizing biofilms.

Shakya and Ghosh [125] demonstrated the removal of nitrate, arsenic, and iron from contaminated groundwater in an anaerobic suspended growth reactor system (SmBR) inoculated with a mixed indigenous bacterial culture. Results showed that the SmBR was able to simultaneously remove nitrate, arsenic, and iron present at different concentrations from real groundwater to levels below the permissible drinking water limits after the addition of sulfate insufficient amount. Furthermore, iron was removed from groundwater through the formation of iron sulfides by the presence of biogenic sulfides, while the main arsenic removal mechanism was through the precipitation of arsenosulfides, co-precipitation, and/or adsorption on iron sulfides.

Moreover, Zhang et al. [126] investigated the biotransformation mechanism of chromium $\mathrm{Cr}$ (VI) as well as the biogeochemical fate of the reduced chromium in groundwater by studying the sulfur-based mixotrophic bio-reduction where $\mathrm{Cr}(\mathrm{VI})$ is the only electron acceptor and organics and elemental sulfur as co-donors of electrons. This study demonstrates the effectiveness of this process in the detoxification process of $\mathrm{Cr}(\mathrm{VI})$ in which $95.5 \%$ removal efficiency was achieved within $48 \mathrm{~h}$ at $50 \mathrm{mg} / \mathrm{L}$ as the initial concentration; these results were higher than the removal efficiency achieved by autotrophic and heterotrophic reductions combined. This process can be implemented for the in situ $\mathrm{Cr}(\mathrm{VI})$ bioremediation in groundwater. Similarly, Panousi et al. [127] studied the removal of $\mathrm{Cr}(\mathrm{VI})$ from highly contaminated groundwater by sequencing batch reactors (SBR) operating under anaerobic conditions where the main electron acceptor was sulfate as well as under anoxic conditions where nitrate was the main electron acceptor. Results showed that the complete reduction of $\mathrm{Cr}(\mathrm{VI})$ to $\mathrm{Cr}$ (III) under an initial $\mathrm{Cr}(\mathrm{VI})$ concentration of $1.8 \mathrm{ppm}$ was supported by the anaerobic conditions of the SBR system. On the other hand, complete removal of $\mathrm{Cr}(\mathrm{VI})$ was achieved under anoxic conditions and $\mathrm{Cr}(\mathrm{VI})$ initial concentration of $10 \mathrm{ppm}$. However, increasing the initial concentration caused a decrease in the removal efficiency under anaerobic conditions. Based on the maximum specific growth

Fig. 2 a Schematic of the simultaneous removal of $\mathrm{Mn}^{2+}, \mathrm{Fe}^{2+}$, and antibiotics in groundwater using peroxymonosulfate (PMS)-assisted in situ oxidation/coagulation $(\mathrm{O} / \mathrm{C})$ coupled with ceramic membrane process [118]. b Simultaneous removal of $\mathrm{NH}_{4}{ }^{+}$and $\mathrm{Mn}^{2+}$ from groundwater using iron-manganese co-oxide filter film $(\mathrm{MeOx})$ as a catalyst [119]. c Simultaneous removal of $\mathrm{Cs}^{+}$and $\mathrm{Sr}^{2+}$ from groundwater using low-cost inorganic ion exchange materials such as sulfur-modified chabazite (CHA) [120] 
a

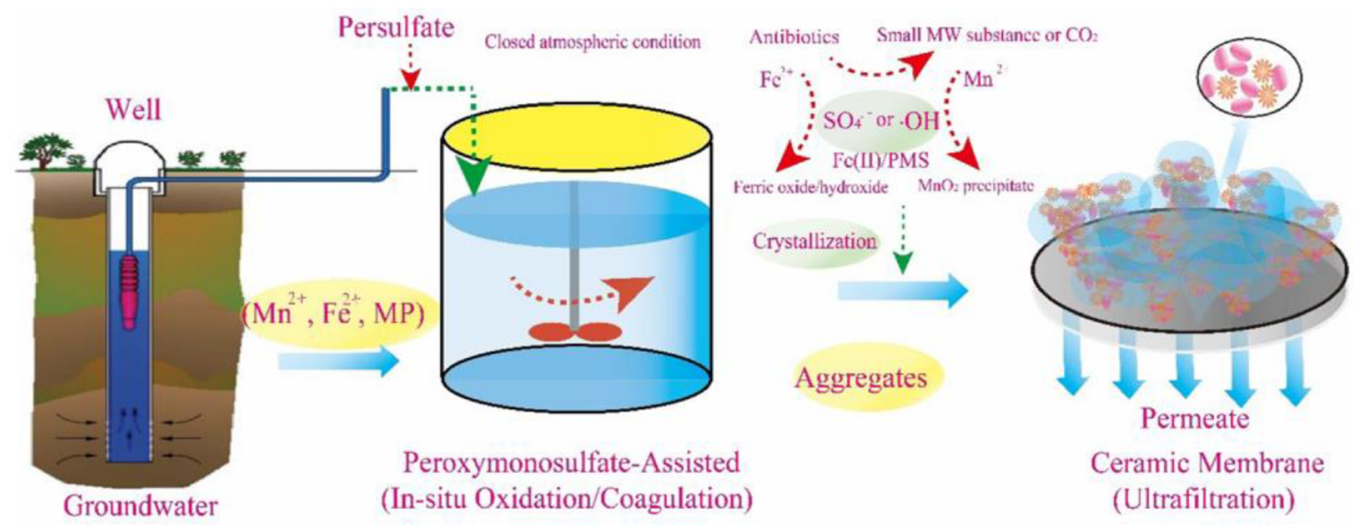

b
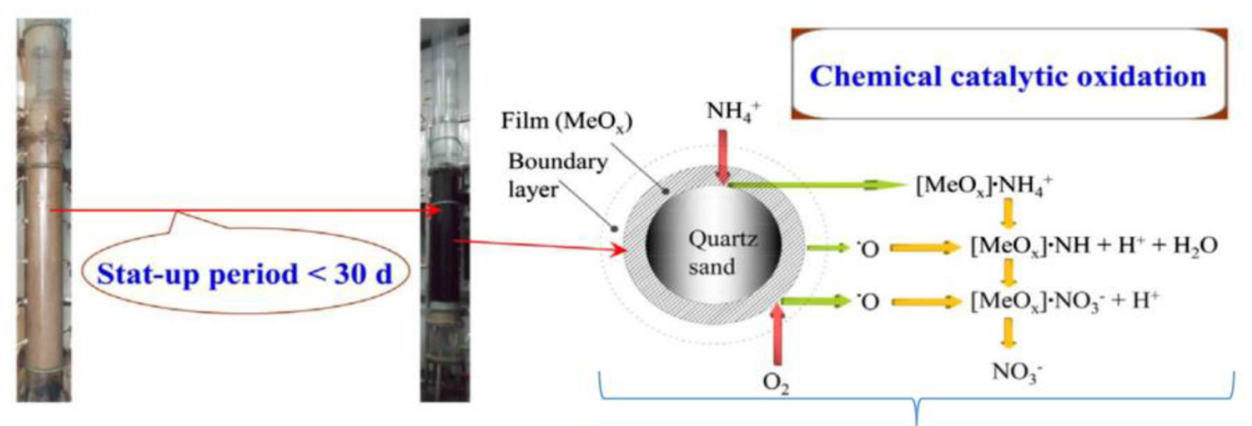

The oxidation process of $\mathrm{NH}_{4}{ }^{*}$ can be presented as a sequence of five main steps (1) Formation of adsorbed $\mathrm{NH}_{4}^{+}$(adsorption on surface),

(2) $\mathrm{O}_{2}$ adsorption to form adsorbed $\mathrm{O}_{2}$, then quickly desorbed to form the active state intermediates ${ }^{\circ} \mathrm{O}$

(3) the reaction between an oxidized ${ }^{\circ} \mathrm{O}$ and adsorbed $\mathrm{NH}_{4}^{+}$to produce $\mathrm{NH}$ and $\mathrm{H}^{*}$ (oxidation of a surface),

(4) the formation of the final product $\mathrm{NO}_{3}$ ' from $\mathrm{NH}$ and oxidized ${ }^{\circ} \mathrm{O}$ (oxidation of a surface), and

(5) desorption of $\mathrm{NO}_{3}{ }^{-}$into the water.

C

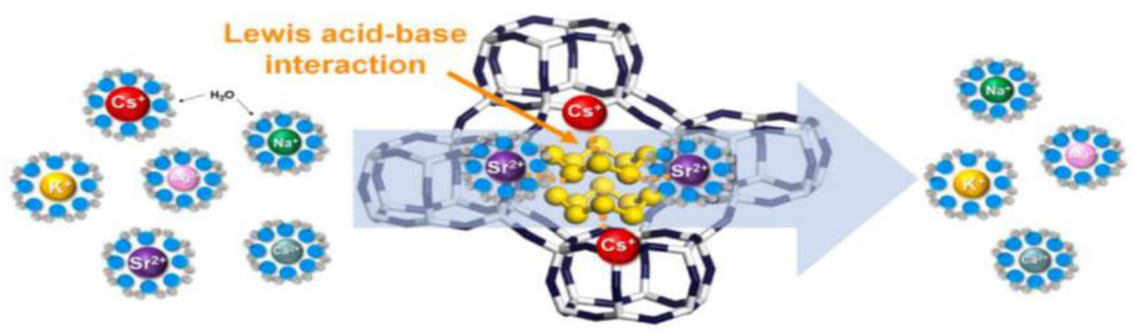

$5 \mathrm{wt} \%$ sulfur in S-chabazite for the selective removal of both ${ }^{137} \mathrm{Cs}$ and ${ }^{90} \mathrm{Sr}$

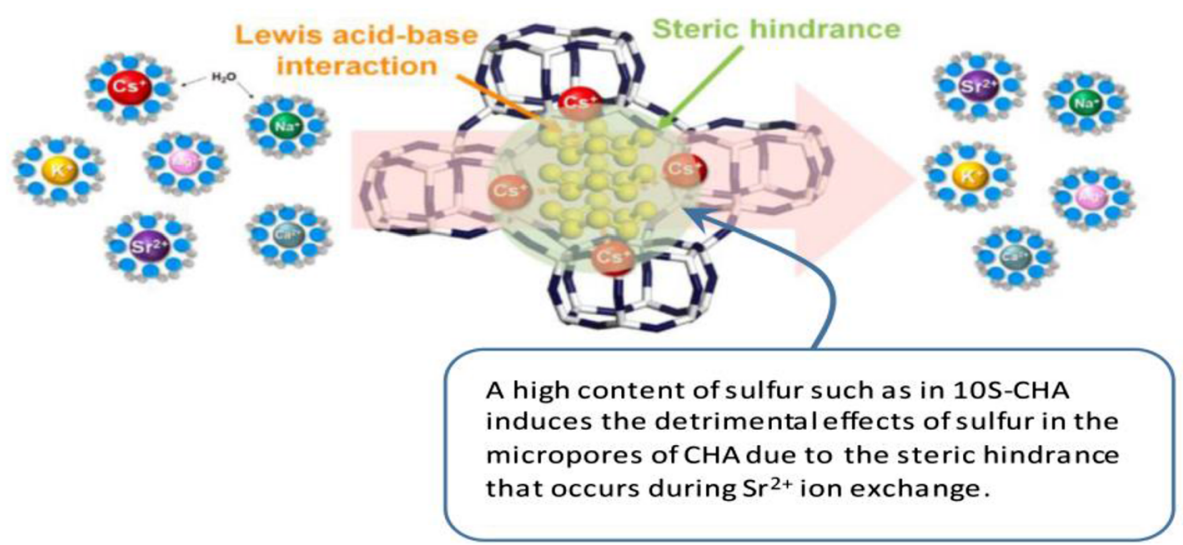


rates, the acclimatized biomass under anaerobic conditions had a much lower tolerance of $\mathrm{Cr}(\mathrm{VI})$ when compared with the acclimatized biomass under anoxic conditions.

da Conceicao et al. [128] investigated the fluoride reduction in groundwater by using coagulation with Moringa oleifera Lam seeds combined with microfiltration. The experiments were performed in a jar test with various coagulant concentrations and then, groundwater was subsequently treated with microfiltration membranes. The results showed that with an initial fluoride concentration of $5 \mathrm{mg} / \mathrm{L}$ and $5 \mathrm{~g} / \mathrm{L}$ of the Moringa oleifera coagulant the obtained treated water had a fluoride residual $(1.2 \mathrm{mg} / \mathrm{L})$ that meets the recommendations of the WHO. Therefore, it is indicated that the combined process of natural and biodegradable coagulant with the microfiltration process provides an alternative treatment for the removal of excessive fluoride from groundwater.

For the removal of molybdenum from groundwater, Carnevale et al. [129] reported the application of brown seaweed (Petalonia fascia) as an adsorbent. The experiments were performed in batch and continuous systems and results showed that the highest adsorption capacity was $1376 \mathrm{mg} / \mathrm{g}$. The high adsorption capacity and low cost of the adsorbent make it a good alternative to be used in the treatment of groundwater from molybdate anions. Aziz et al. [130•], on the other hand, determined the use of Moringa oleifera seeds and Musa cavendish peel as low-cost plant-based biomass for the simultaneous removal of nickel, lead, and cadmium ions from groundwater. The used plant-based biomass was pretreated by $\mathrm{HNO}_{3}$ and then by $\mathrm{NaOH}$ for the enhancement of its treatment efficiency. Results indicated the efficiency of the used biomass in the removal of the tested heavy metals due to the presence of various functional groups, which were playing the main role in the removal mechanism, namely $\mathrm{C}-\mathrm{C}, \mathrm{C}=\mathrm{O}$, and $\mathrm{N}-\mathrm{H}$. Results showed that increasing the initial concentration of lead ions increased the removal efficiency by Moringa oleifera seed from 65 to $81 \%$ and a similar trend was observed when both biomass (Moringa oleifera + Musa cavendish) were used for the adsorption of lead ions. However, nickel removal by Moringa oleifera decreased with increasing the initial nickel concentration. On the other hand, higher removal efficiency was observed when using Moringa oleifera + Musa cavendish at a high initial concentration of nickel or cadmium when compared to the use of a single adsorbent. Furthermore, $\$ 17$ was the total cost for the treatment of $50 \mathrm{~L}$ groundwater, which proves the suitability of this treatment technique for communities with lower income.

Al-Mamun et al. [131] presented the feasibility of continuous up-flow baffled microbial fuel cells (MFCs) with carbon brush electrodes for the oxidization of organics present in the sewage by the exoelectrogens on the anode producing electricity and simultaneously removal of nitrogen from groundwater by using the generated electricity. Anaerobic sequencing batch reactor (ASBR) was integrated before the MFCs to remove nitrogen from groundwater. It was revealed that the integration of ASBR with the biocathode increased the nitrogen removal from groundwater by $136 \%$ that is higher than the removal without the ASBR system. The obtained results indicate the efficiency of using the ASBR system as pretreatment and using the solubilized organics successively in denitrifying biocathode MFC for the simultaneous recovery of energy as well as nitrogen removal from groundwater. Similarly, the removal of $\mathrm{NH}_{4}{ }^{+}-\mathrm{N}, \mathrm{NO}_{2}{ }^{-}-\mathrm{N}$, and $\mathrm{NO}_{3}{ }^{-}-\mathrm{N}$ from groundwater was achieved through adsorption by the composite active medium of nitrogen-degrading bacteria immobilized consortia [132]. The ability of the composite active medium to remove nitrogen was found to be significantly enhanced by the immobilization of the degrading bacteria on scoria in comparison with the use of scoria alone. Pseudomonas, Stenotrophomonas, and Serratia were found to be the best bacterial genera for effective removal of nitrogen in its three tested forms.

Mollamohammada et al. [133] determined the capability of using Scenedesmus sp. immobilized on alginate gel for the simultaneous removal of nitrate, magnesium, phosphorus, and zinc from groundwater in a continuous flow reactor (Table 6). Results showed that immobilized Scenedesmus sp. beads were able to simultaneously remove $92 \%, 100 \%$, $99.9 \%$, and $92 \%$ of nitrate, magnesium, phosphorus, and zinc from groundwater after 29 days, respectively. Zhou et al. [134] identified the effect of sulfate on the simultaneous removal of nitrate and selenate from groundwater by a hydrogen-based membrane biofilm reactor (MBfR). Results showed that sulfate had no obvious effect on the removal of both selenate and nitrate as almost $100 \%$ removal efficiency was achieved. Furthermore, the microbial ecology indicated that the stable and efficient degradation of nitrate was achieved by Hydrogenophaga as one of the contributors, while Desulfovibrionaceae promoted the degradation of selenate. However, other microorganisms that exist in groundwater are considered a source of contamination.

The bioremediation of vanadium from groundwater was also done by sawdust pine as a carbon source and anaerobic sludge as inocula [135]. The $90.3 \%$ removal efficiency was achieved in nutrient solution and the accumulation of microbes such as Thauera could contribute to the reduction of vanadium. The reduction of vanadium was mediated by the microbes' synergistic interactions. Furthermore, in real groundwater; the vanadium removal could be increased from 53.2 to $82.6 \%$ by adding phosphate rock and medical stone.

\section{Removal of Microorganisms from Groundwater}

The presence of pathogens (bacteria, viruses, and protozoa) in groundwater is a worldwide concern for public health. Many 
studies have shown the presence of a variety of pathogens in groundwater that have been associated with different disease outbreaks [136]. These outbreaks can be detected by linking the information related to the increase in illness in the population exposed to the presence of pathogens in the water consumed. However, in routine practice, many outbreaks caused by contaminated water remain unrecognized, as it is difficult to link the increase in illness to the presence of causative agents in water. Moreover, the detection of pathogens in water samples is also more complicated as compared to biological samples [137]. Commonly found pathogens in water are Cryptosporidium parvum, Giardia intestinalis, Campylobacter jejuni, norovirus, and others [138, 139••].

Generally, there are various techniques that have been used for the removal of pathogens from water, such as sand filtration, disinfection (UF, ozone, chorine), adsorption, filtration, and activated sludge systems, which are discussed below. For example, Andreoli and Sabogal-Paz [140] investigated the performance of two different settings of household slow sand filters HSSF, namely intermittent (I-HSSF) and continuous (C-HSSF) flow that are followed by sodium hypochlorite for disinfection to simultaneously remove Escherichia coli, Giardia muris cysts, and Cryptosporidium parvum oocysts from groundwater. Two operation phases were evaluated in this study to accelerate the HSSF ripening, with and without the use of river water as a ripening agent. A ripening agent usually is introduced to the filter to provide nutrients for the development of the biological layer in a short time. Results showed that better removal efficiency of microbes in groundwater was achieved by C-HSSF when compared to I-HSSF. Furthermore, it was observed that the weekly feeding of HSSFs with river water as a ripening agent sped up the ripening process in around 80 days, which in turn lead to treatment efficiency improvement compared to the operation without the ripening agent. The obtained results indicated the applicability of HSSF in rural communities to provide safe water.

Alvear-Daza et al. [141••] evaluated the simultaneous removal of Escherichia coli and Klebsiella pneumoniae from groundwater by coupled helio-photochemical processes with artificial UVB + UVA + visible light in the presence of $\mathrm{H}_{2} \mathrm{O}_{2}$ with rapid sand filtration and chlorination step. Results indicated that several natural photo-induced processes such as photocatalytic and photo-Fenton could be enhanced by the simple attrition of $\mathrm{H}_{2} \mathrm{O}_{2}$ and natural sunlight as well as artificial light irradiation, as the total reduction of Escherichia coli and Klebsiella pneumoniae could be due to such radicals. To remove pathogenic bacteria from groundwater, MpenyanaMonyatsi et al. [142] developed low-cost filter materials coated with silver nanoparticles that were deposited on zeolite, sand, fiberglass, and anion and cation resin substrates in different concentrations for the simultaneous removal of pathogens from groundwater. Results showed that using $\mathrm{Ag}$ /cation resin achieved $100 \%$ removal efficiency of E. coli,
S. typhimurium, S. dysenteriae, and V. cholerae, while other filters had lower removal efficiency in the range of 8 to $67 \%$. The obtained results suggested the use of $\mathrm{Ag} / \mathrm{cation}$ resin as a disinfection technique for groundwater.

Adsorption technique, as a cost-effective technology, has been used for the removal of pathogenic microorganisms from water. For example, Chung et al. [143] determined the simultaneous removal of pathogenic rotavirus and adenovirus from groundwater by hydrochar derived from sewage sludge amended sand beds as an adsorbent. Results showed that more than $99 \%$ removal efficiency was achieved that is corresponding to 2.4-log removal of both viruses by the used adsorbent. The introduction of hydrophobic and/or meso-/macro-surface structure of the hydrochar could be responsible for the improved removal efficiency in which it provided favorable attachment sites for rotavirus and adenovirus. Obijole et al. [144] prepared hydrothermally treated aluminosilicate clay for the simultaneous removal of fluoride and bacteria from water. The prepared adsorbent had an adsorption capacity of $1.75 \mathrm{mg} / \mathrm{g}$ for fluoride ions and removed $53 \%$ of fluoride from water. Moreover, the efficiency of the prepared materials was noted against E. coli in terms of zone of inhibition for bacterial growth.

Some researchers have also applied nanocomposites for the successful removal of pathogenic microorganisms from water. Ayinde et al. [145] combined microwave and ultrasonically modified methods as a greenway for the synthesis of multifunctional $\mathrm{Ag}-\mathrm{MgOH}$ ap nanocomposite. The impregnation of the reduced $\mathrm{Ag}$ and $\mathrm{MgO}$ nanoparticles on the adsorbent surface occurred by Citrus paradisi peel extract to evaluate its antimicrobial activity against Escherichia coli and Klebsiella pneumonia in groundwater. Results indicated that the synthesized nanocomposite has a strong and effective antibacterial activity towards Escherichia coli and Klebsiella pneumonia. It was shown that Escherichia coli were more susceptible than Klebsiella pneumonia with an inhibition zone of $13 \mathrm{~mm}$ and $10 \mathrm{~mm}$, respectively. The antimicrobial activity of the nanocomposite and the death of the cell membrane for the microbes could be attributed to the penetration of both $\mathrm{Ag}$ and $\mathrm{MgO}$ ions that were released from the nanoparticles on the adsorbent surface as well as their interaction with the bacterial genome and other cellular enzymes. Ayinde et al. [63・•] also investigated the green synthesis of metal-metal oxide nanoparticles supported on chitosan matrix (AgMgO/nHaP@CSn) for the simultaneous removal of pathogens from groundwater. Results showed that the inhibition zone for gram-positive Staphylococcus aureus was higher than that for gram-negative Escherichia coli. The AgMgO/nHaP@CSn nanocomposite mechanism could be due to the inherent synergistic antibacterial activity of these nanomaterials. These synergistic properties include the wide contact interaction because of the larger surface area as well as the surface charges 
between the nanocomposite and the bacterial cell wall. These results indicate the nanocomposite potential to treat groundwater contaminated with pathogens. Similarly, Sivaselvam et al. [146] prepared $\mathrm{MgO}$ nanostructures of variable shapes (spherical and cubicle) to test their antibacterial activity in water. It was noted that both nanostructures were able to inhibit bacterial growth by inducing intracellular production of reactive oxygen species (ROS) and by physically damaging the surface of the bacterial cell.

Magnetic nanoparticles (MNPs) have also gained significant attention owing to their superior properties and characteristics. However, grafting these magnetic nanoparticles with amino functional groups has further improved their performances against a variety of pollutants including heavy metals, microorganisms, and other organic pollutants in water [146]. The antibacterial activities of green synthesized iron nanoparticles (FeNPs) using leaf and seed extract of Moringa oleifera (M. oleifera) were tested against Escherichia coli (E. coli) [147]. The antibacterial activity results showed that $M$. oleifera leaf is less resistant to E. coli as it had an inhibition zone of $5 \mathrm{~mm}$, while M. oleifera seed was more resistant with an inhibition zone of $6 \mathrm{~mm}$. The positively charged $\mathrm{Fe}$ ion may be the reason for the antibacterial activity through the attraction between the microorganisms' negatively charged cell membrane.

\section{Advancement of Sorbents for Various Pollutants Through Material Design}

This section mainly discusses and explores the rational material design to combine the interaction mechanisms for the simultaneous removal of various contaminants such as heavy metals as shown in Fig. 3. Graphene-based sorbents are used as model sorbents as they can be designed in different ways such as shaping them into various forms like hydrogels, aerogels, fluids, powder, and particles; optimizing their textural properties and their chemical functionality can be tailored for various treatment applications. Moreover, the binding tendency of charged pollutants such as heavy metal ions towards the graphene surface can be increased because of the generated surface charge on the graphene surface as well as its counterparts through the heteroatom doping and functionalization. Groups containing oxygen, nitrogen, and sulfur are commonly introduced to the framework of graphene in which the grafting process can be achieved through thermal annealing, plasma treatments, wet chemical methods, microwave synthesis, hydrothermal, and solvothermal [148, 149]. Modification strategies including heteroatom doping (such as phosphorus, nitrogen, boron, and sulfur) and chemical functionalization that can be applied to graphene-based sorbents can enhance its adsorption performance in the removal process of pollutants from water. This is due to the challenges faced by the synthesis of graphene-based sorbents as it is still
Fig. 3 Various interaction types involved in the adsorption of heavy metals onto graphenebased sorbent [155]

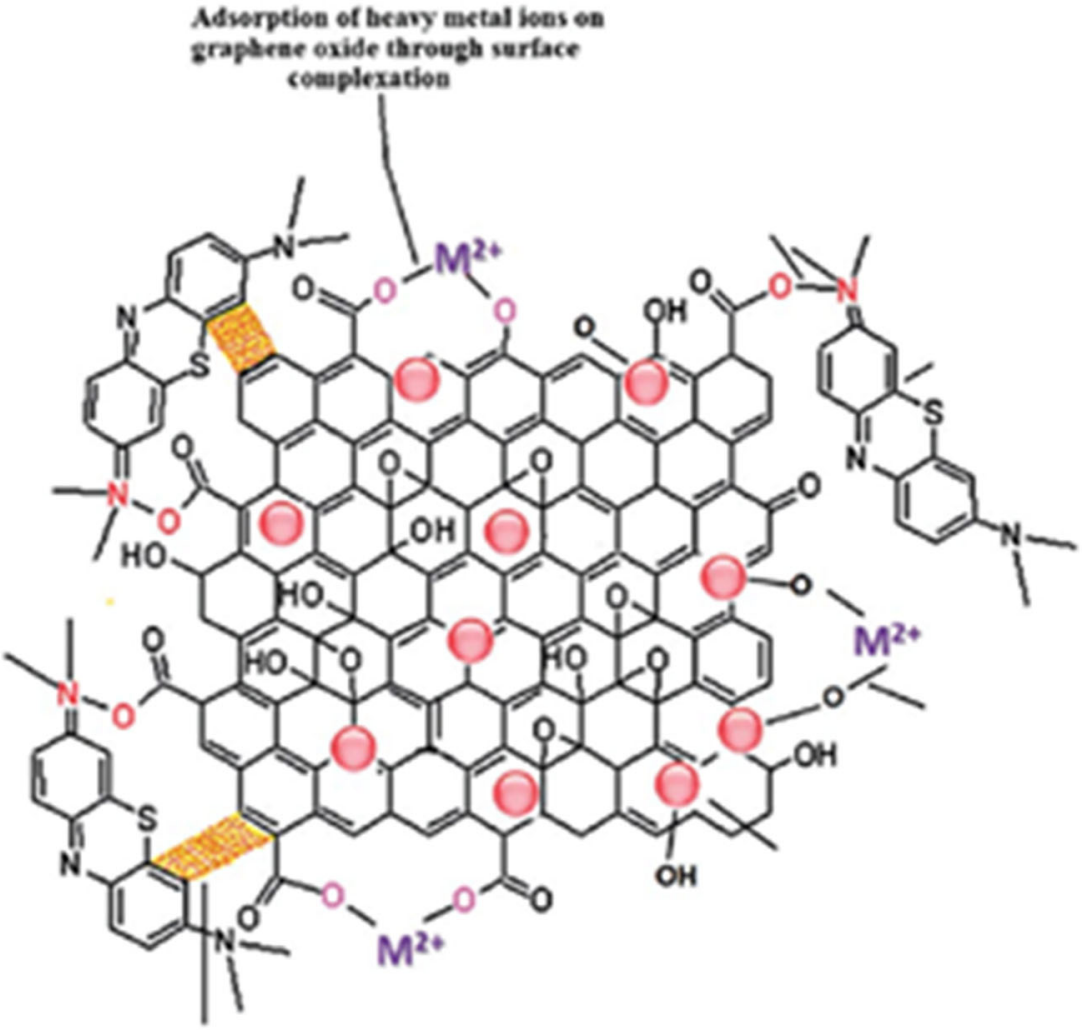


limited by the chemical inertness, high hydrophobicity, low water dispersion, and its tendency to undergo $\pi-\pi$ stacking [150]. The cost of applying the advanced graphene sorbent is a barrier that limits its application. However, the treatment cost should take into consideration the treatment time, performance efficiency, and regeneration feasibility to achieve a sustainable water treatment technology. Since using graphene-based adsorbents has a high regeneration rate, high-performance efficiency, and only a small amount of it is required to treat large volumes of polluted groundwater, it can be considered a promising economically feasible treatment process in comparison to other commercial sorbents like activated carbon [151].

Pan et al. [152] investigated the simultaneous removal of lead, copper, and cadmium from groundwater by fabricating a porous calcium alginate/graphene oxide composite aerogel by utilizing polystyrene colloidal particles as a sacrificial template and graphene oxide as a reinforcing filler to achieve high adsorption capacity. Results showed the removal rates of $95.4 \%, 81.2 \%$, and 73.2 , for lead, copper, and cadmium, respectively. It has been indicated by the analysis of the adsorption mechanism that the adsorption process occurred mainly through chemical coordination effects and ion exchange. Zare-Dorabei et al. [153] synthesized graphene oxide that is chemically modified with 2,2'-dipyridylamine (GO-DPA) for the simultaneous removal of lead, cadmium, nickel, and copper from groundwater. Results showed that the maximum adsorption capacities achieved were $369.7 \mathrm{mg} / \mathrm{g}, 257.2 \mathrm{mg} / \mathrm{g}$, $180.9 \mathrm{mg} / \mathrm{g}$, and $358.2 \mathrm{mg} / \mathrm{g}$ for lead, cadmium, nickel, and copper ions, respectively. Furthermore, chemical modification of graphene oxide with 3-aminopyrazole (GO-f) was synthesized for the simultaneous removal of cadmium, mercury, and arsenic from groundwater due to the important role played by the nitrogen-containing functional groups existing on the surface of the adsorbent [154]. Results showed that the adsorption affinity order was cadmium $>$ mercury $>$ arsenic with an adsorption capacity of $285.7 \mathrm{mg} / \mathrm{g}, 227.3 \mathrm{mg} / \mathrm{g}$, and 131.6 $\mathrm{mg} / \mathrm{g}$, respectively. The obtained results could be attributed to the presence of functional moieties and hydrophilic character as well as the high surface area of GO-f. Pirveysian and Ghiaci [155] used $\mathrm{Na}_{2} \mathrm{~S}$ as a functionalizing precursor in developing sulfur functionalized graphene oxide (GO$\mathrm{SO}_{\mathrm{x}} \mathrm{R}$ ) sorbent for the simultaneous removal of lead, cadmium, nickel, and zinc, in which outstanding maximum adsorption capacities of $285 \mathrm{mg} / \mathrm{g}, 217 \mathrm{mg} / \mathrm{g}, 175 \mathrm{mg} / \mathrm{g}$, and $196 \mathrm{mg} / \mathrm{g}$ were obtained for the investigated metals, respectively. Moreover, in this study, $\mathrm{GO}_{-} \mathrm{SO}_{\mathrm{x}} \mathrm{R}$ was coated with $\mathrm{TiO}_{2}$ and $\mathrm{SiO}_{2}$ to improve the sorbent adsorption capacity. Results showed that $\mathrm{SiO}_{2}$ improved the removal rate of cadmium only, while $\mathrm{TiO}_{2}$ showed higher adsorption capacities for all heavy metals as it increased to $312 \mathrm{mg} / \mathrm{g}$, $384 \mathrm{mg} / \mathrm{g}, 344 \mathrm{mg} / \mathrm{g}$, and $285 \mathrm{mg} / \mathrm{g}$, for lead, cadmium, nickel, and zinc, respectively.

\section{Practical Implications and Challenges of Groundwater Treatment}

The effective management of groundwater requires attention for securing the water requirements of agricultural and industrial activities. This paper reviews the cost-efficient treatment techniques for the simultaneous removal of multi-elements and microorganisms from groundwater and the removal mechanisms of certain contaminants by using specific treatment techniques, as well as the challenges and cost analysis of groundwater treatment. However, there are various challenges that face the application of economic instruments for the treatment of groundwater such as (i) time lags of contaminants as they take a long time before reaching the aquifer, causing difficulty in monitoring the effectiveness of the protection measures. Furthermore, the variability of the time lags depends on several factors, namely precipitation, soil type, or saturation. (ii) Hydrogeological conditions of the contaminated site determine the impact of the contaminant; such conditions include topsoil layer, soil type, aquifer's depth, and volume, as well as its connections to surface water bodies; and (iii) prediction of the location-specific economic shifts that occur due to the rise in water prices as well as finding ways to reduce it [156].

For instance, the ion exchange technique is a promising technique for the treatment of water with no generation of sludge, but this process is limited to specific pollutants as well as requires a high cost for the replacement of the resin over time. Although the membrane filtration process is efficient in water treatment and can have high removal capacities without the generation of secondary pollution, its high manufacturing costs, severe fouling, and high-energy consumption are major drawbacks that limit its application. It is also strongly indicated that adsorption is considered an efficient treatment technique for the removal of various contaminants from groundwater by utilizing different adsorbents. However, prior to the implementation of the adsorption process for the treatment of groundwater, the cost of adsorbent regeneration should be considered, as some regeneration processes are energyintensive and costly. In such cases, other treatment options should be investigated such as biological treatment techniques. Treating groundwater in a biological treatment system can greatly influence the requirements and cost of disposing of spent adsorbents and sludge, which will contain metals and other pollutants.

Furthermore, the cost of the treatment depends on the quality of groundwater as, if it has good quality, several treatment processes will be neglected which in turn reduces the treatment cost. On the other hand, the treatment cost will increase when the water has a very low quality due to the increased chemical usage. Moreover, cost analysis has a significant variation between different contamination sites, and various factors that could impact the treatment cost are site-specific 
[157]. Figure 4 summarizes how to determine the best treatment option [158, 159]. According to Reddy [159], the characterization of the contamination site before assessing the hazardous risk is of utmost importance as the characterization includes defining the site's geology, hydrology, and contamination, locations, and demographics of the nearby populations, as well as the potential releases to the environment. After that, a hazardous risk assessment for the contaminated site can be performed and the appropriate treatment action can be selected. Treating specific contamination requires the understanding of subsurface conditions as well as the advantages and disadvantages of each treatment technique that can be used. This is important to avoid making the contamination site worse by choosing and implementing improper treatment techniques. Since there are various treatment technologies for groundwater remediation, for choosing the best treatment option in terms of economic and effective treatment, five strategies for the assessment of treatment techniques are proposed [160]:

1. Understanding the requirements of the treatment as well as the implications of water quality comparing the quality of raw water with the goal of the treatment for the determination of the suitable treatment requirements and processes.

2. Choosing the optimal treatment technology, knowing the advantages and disadvantages of each treatment process, helps in determining which treatment to be used for specific contaminated groundwater. Some techniques are capable of removing several contaminants while others can only remove a few target pollutants.

3. Pretreatment processes might be needed to increase treatment efficiency.
Fig. 4 Summary of steps required for choosing the appropriate groundwater treatment technique

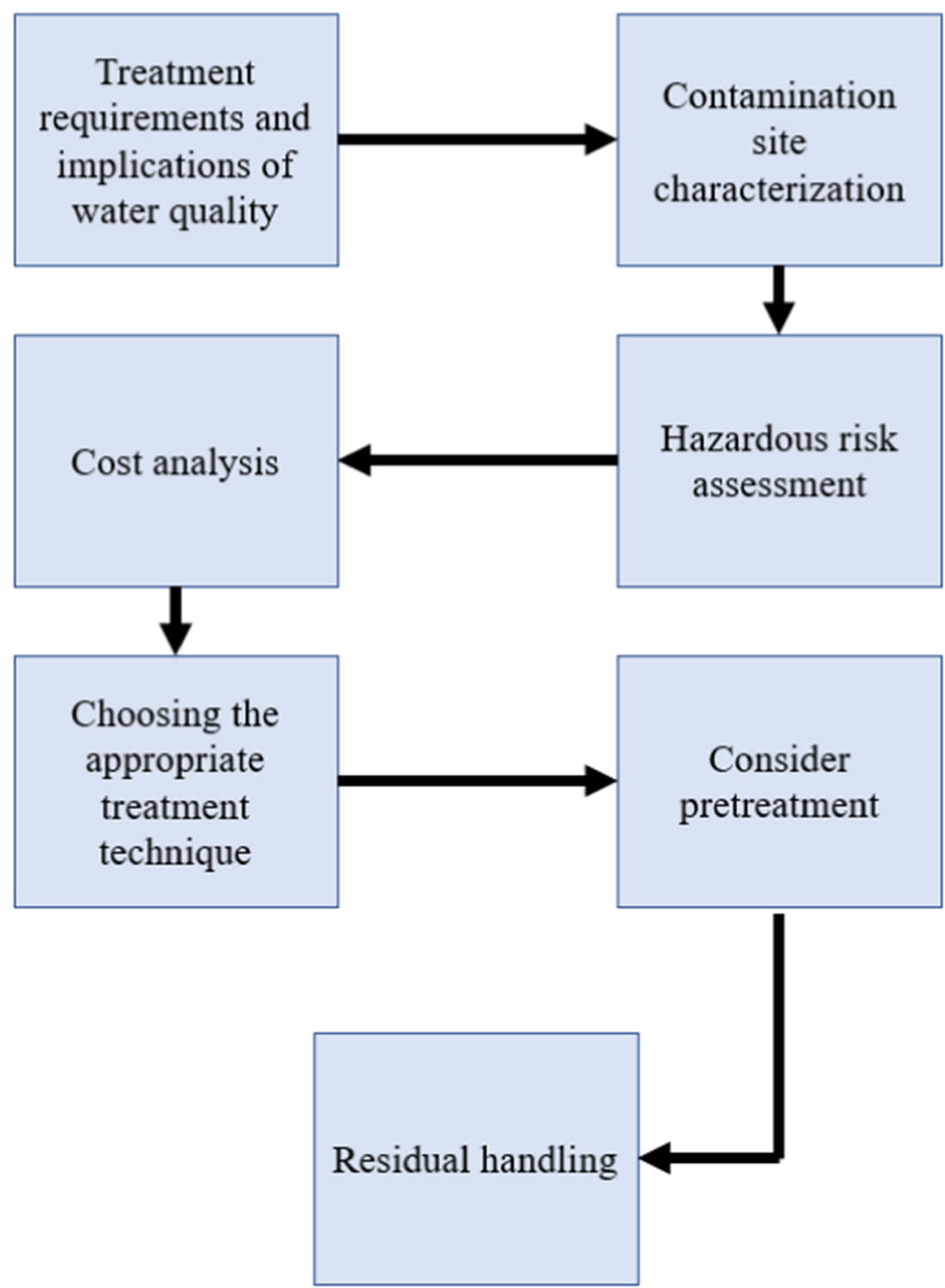


4. Handling the residuals, the residual handling requirements differ depending on the used treatment technology. For example, the adsorption process requires the replacement of the used media and some rinse to sewer, while biological filtration requires waste backwashing.

5. Biological filtration is a cost-effective process that does not demand high-energy consumption. It can remove different contaminants without multiple add-on unit processes.

Currently, the development of accurate comparison for the cost of treatment technologies is difficult due to various significant problems. Firstly, extrapolation of the reported costs under specific conditions at one site to other sites is very difficult. This can be attributed to the sensitivity of technology costs towards site-specific geological, geochemical, and contaminant conditions. Secondly, costs could be reported in various metrics that cannot be directly compared, such as the achieved reduction in the concentration of contaminants, dollars per treated volume, or surface area treated. These differences in cost reporting metrics make a comparison between the costs of different technologies by utilizing previous data at different sites very difficult. Thirdly, usually variable costs are not reported, namely system design, equipment mobilization to the contaminated site, or modification for site conditions. Lastly is the inconsistency in the derived way of costs [161].

\section{Conclusion}

In conclusion, groundwater is considered one of the main sources for agricultural, industrial, and drinking purposes. Unfortunately, anthropogenic and natural contamination has degraded the quality of groundwater and limited its usage around the world. In the literature, various studies have reported the contamination of metals like lead, boron, and cadmium in groundwater. The presence of various pathogenic viruses and bacteria has also been reported in the groundwater. Hence, the monitoring and treatment of groundwater have become highly important for the protection of public health and the environment.

There are several treatment techniques for the removal of such contaminants from groundwater and their capabilities vary from one to another. However, some techniques have drawbacks in terms of high-energy demands and cost in-effectiveness. In this paper, various examples of low-cost treatment techniques for the removal of different metals and microorganisms and their removal mechanisms were discussed. The criteria for choosing the right treatment technique were also discussed such as characterization and hydrogeological aspects of the contaminated site, hazardous risk assessment, the goal of the treatment (i.e., reuse options), and cost-benefit analysis. Finally, it is recommended that future research should aim to understand the transport and fate of various emerging contaminants (metals, pathogens, and others) and should target to evaluate the treatment techniques for the removal of such water contaminants. Additionally, scientists from different disciplines (microbiologists, environmental engineers, and material scientists) should work together to develop water remediation techniques that can ensure the protection of natural water resources and public health and safety.

Funding Open access funding provided by the Qatar National Library. This publication was made possible by NPRP grant \# 12S-0307-190250 from the Qatar National Research Fund (a member of Qatar Foundation).

\section{Compliance with Ethical Standards}

Conflict of Interest On behalf of all authors, the corresponding author states that there is no conflict of interest.

Human and Animal Rights and Informed Consent This article does not contain any studies with human or animal subjects performed by any of the authors.

Disclaimer The findings achieved herein are solely the responsibility of the author(s).

Open Access This article is licensed under a Creative Commons Attribution 4.0 International License, which permits use, sharing, adaptation, distribution and reproduction in any medium or format, as long as you give appropriate credit to the original author(s) and the source, provide a link to the Creative Commons licence, and indicate if changes were made. The images or other third party material in this article are included in the article's Creative Commons licence, unless indicated otherwise in a credit line to the material. If material is not included in the article's Creative Commons licence and your intended use is not permitted by statutory regulation or exceeds the permitted use, you will need to obtain permission directly from the copyright holder. To view a copy of this licence, visit http://creativecommons.org/licenses/by/4.0/.

\section{References}

Papers of particular interest, published recently, have been highlighted as:

- Of importance

•• Of major importance

1. Parkinson C. Coming climate crisis? Rowman \& Littlefield; 2012.

2. Jakeman A, Barreteau O, Hunt R, Rinaudo J, Ross A. Integrated groundwater management. Springer International Publishing; 2016. https://doi.org/10.1007/978-3-319-23576-9

3. Caridi F, Messina M, D’Agostino M. An investigation about natural radioactivity, hydrochemistry, and metal pollution in groundwater from Calabrian selected areas, southern Italy. Environ Earth Sci. 2017;76. https://doi.org/10.1007/s12665-017-7031-9 This study investigated the groundwater contamination with metals at different areas in Italy.

4. FAO. AQUASTAT Database. 2017. AQUASTAT Website Accessed 17/03/2021 19:15. 
5. Rodriguez-Espinosa P, Sabarathinam C, Ochoa-Guerrero K, Martínez-Tavera E, Panda B. Geochemical evolution and boron sources of the groundwater affected by urban and volcanic activities of Puebla Valley, south central Mexico. J Hydrol. 2020;584: 124613. https://doi.org/10.1016/j.jhydrol.2020.124613 This study explains how urban and volcanic activities affect the groundwater composition and contamination by boron.

6. World Health Organization. WHO/UNICEF Joint Water Supply and Sanitation Monitoring Programme, World Health Organization (2015). 2015. Update and MDG Assessment.

7. Kumar M, Goswami R, Patel A, Srivastava M, Das N. Scenario, perspectives and mechanism of arsenic and fluoride co-occurrence in the groundwater: a review. Chemosphere. 2020;249:126126. https://doi.org/10.1016/j.chemosphere.2020.126126.

8. Ghrefat H, Nazzal Y, Batayneh A, Zumlot T, Zaman H, Elawadi $\mathrm{E}$, et al. Geochemical assessment of groundwater contamination with special emphasizes on fluoride, a case study from Midyan Basin, northwestern Saudi Arabia. Environ Earth Sci. 2013;71(4): 1495-505. https://doi.org/10.1007/s12665-013-2554-1.

9. Verma S, Mukherjee A, Choudhury R, Mahanta C. Brahmaputra river basin groundwater: solute distribution, chemical evolution and arsenic occurrences in different geomorphic settings. J Hydrol. 2015;4:131-53. https://doi.org/10.1016/j.ejrh.2015.03.001.

10. Manickum T, John W, Terry S, Hodgson K. Preliminary study on the radiological and physicochemical quality of the Umgeni Water catchments and drinking water sources in KwaZulu-Natal. South Africa J Environ Radioact. 2015;137:227-40. https://doi.org/10. 1016/j.jenvrad.2014.07.015.

11. Guidelines for drinking-water quality: fourth edition incorporating the first addendum. Geneva: World Health Organization. 2017. Licence: CC BY-NC-SA 3.0 IGO.

12. USEPA.2018 Edition of the Drinking Water Standards and Health Advisories. 2018. Office of Water, U.S. Environmental Protection Agency, Washington, DC. EPA 822-F-18-001.

13. Alshehri F, Almadani A, El-Sorogy A, Alwaqdani E, Alfaifi H, AlharbI T. Influence of seawater intrusion and heavy metals contamination on groundwater quality, Red Sea coast, Saudi Arabia. Marine Poll Bullet 2021;165:112094. This recent study shows the effect of seawater intrusion on quality of groundwater.

14.. Ahmad A, Al-Ghout M, Khraisheh M, Zouari N. Hydrogeochemical characterization and quality evaluation of groundwater suitability for domestic and agricultural uses in the state of Qatar. Groundwat Sustain Develop 2020;11: 100467. https://doi.org/10.1016/j.gsd.2020.100467. This article evaluates the quality and quantity of groundwater resources in Qatar using a variety of statistical and geostatistical tools and discusses its application for agricultural purposes.

15.• Sharmin S, Mia J, Miah M, Zakir H. Hydrogeochemistry and heavy metal contamination in groundwaters of Dhaka metropolitan city, Bangladesh: Assessment of human health impact. Hydrol Res. 2020;3:106-17 A recent case study related to the assessment of human health impacts caused by heavy metal contamination in groundwater in Bangladesh.

16. Long X, Liu F, Zhou X, Pi J, Yin W, Li F, et al. Estimation of spatial distribution and health risk by arsenic and heavy metals in shallow groundwater around Dongting Lake plain using GIS mapping. Chemosphere. 2021;269:128698.

17. Adeyemi A, Ojekunle Z. Concentrations and health risk assessment of industrial heavy metals pollution in groundwater in Ogun state. Nigeria Scie Afr. 2021;11:e00666.

18. Ashraf S, Rizvi N, Rasool A, Mahmud T, Huang G, Zulfajri M, et al. Evaluation of heavy metal ions in the groundwater samples from selected automobile workshop areas in northern Pakistan. Groundwat Sustain. Develop. 2020;11:100428 This research demonstrates the role of automobile workshops in groundwater contamination.

19. Qiaoa J, Zhua Y, Jiab X, Shaoa M, Niub X, Liuc J. Distributions of arsenic and other heavy metals, and health risk assessments for groundwater in the Guanzhong Plain region of China. Environ Res. 2020;181:108957.

20. Sirajudeen J, Pravinkumar J. Heavy metal analysis of groundwater of Thirukoviloor, Villuppuram, Tamil Nadu. India Materials. 2021;36:828-31.

21. Rezaeia A, Hassania H, Hassanib S, Jabbaric N, Mousavid S, Rezaei S. Evaluation of groundwater quality and heavy metal pollution indices in Bazman basin, southeastern Iran. Groundw Sustain Dev. 2019;9:100245.

22. Sorensen J, Lapworth D, Read D, Nkhuwa D, Bell R, Chibesa M, et al. Tracing enteric pathogen contamination in sub-Saharan African groundwater. Sci Total Environ. 2015;538:888-95.

23.• Cioffi B, Monini M, Salamone M, Pellicanò R, Bartolo I, Guida $\mathrm{M}$, et al. Environmental surveillance of human enteric viruses in wastewaters, groundwater, surface water and sediments of Campania Region. Reg Stud Mar Sci. 2020;38:101368 This study has demonstrated the presence of human enteric viruses in groundwater.

24. Chik A, Emelko M, Anderson W, O'Sullivan K, Savio D, Farnleitner A, et al. Evaluation of groundwater bacterial community composition to inform waterborne pathogen vulnerability assessments. Sci Total Environ. 2020;743:140472.

25. Wua G, Yanga J, Jianga H, Dengb Y, Learc G. Distribution of potentially pathogenic bacteria in the groundwater of the Jianghan Plain, central China. Int Biodeterior Biodegrad. 2019;143:104711.

26. Ganiyu G, Mabunmi A, Olurin O, Adeyemi A, Jegede O, Okeh A. Assessment of microbial and heavy metal contamination in shallow hand-dug wells bordering Ona River. Southwest Nigeria Environ Monit Assess. 2021;193:126.

27. Cooray T, Zhang J, Zhong H, Zheng L, Wei Y, Weragoda S, et al. Profiles of antibiotic resistome and microbial community in groundwater of CKDu prevalence zones in Sri Lanka. J Hazard Mater. 2021;403:123816.

28.• Stokdyk J, Firnstahl A, Walsh J, Spencer S, Lambert J, Anderson A, et al. Viral, bacterial, and protozoan pathogens and fecal markers in wells supplying groundwater to public water systems in Minnesota, USA. Water Res. 2020;178:115814 This article demonstrates the groundwater contamination with variety of pathogens (bacterial, viral, and protozoans).

29. Sethi R, Di Molfetta A. Remediation of contaminated groundwater. In: Groundwater engineering. Springer Tracts in Civil Engineering. Vol 1. Springer; 2019. 10.1007/978-3-030-20516$4 \_17$

30. Favara P, Gamlin J. Utilization of waste materials, non-refined materials, and renewable energy in in situ remediation and their sustainability benefits. J Environ Manag. 2017;204:730-7. https:// doi.org/10.1016/j.jenvman.2017.03.097.

31. Cecconet D, Sabba F, Devecseri M, Callegari A, Capodaglio A. In situ groundwater remediation with bioelectrochemical systems: a critical review and future perspectives. Environ Int. 2020;137: 105550. https://doi.org/10.1016/j.envint.2020.105550.

32. Khawaja H, Zahir E, Asghar M, Asghar M. Graphene oxide decorated with cellulose and copper nanoparticle as an efficient adsorbent for the removal of malachite green. Int J Biol Macromol. 2020;167:23-34. https://doi.org/10.1016/j.ijbiomac.2020.11.137.

33. Liu Q, Li Y, Chen H, Lu J, Yu G, Moslang M, et al. Superior adsorption capacity of functionalised straw adsorbent for dyes and heavy-metal ions. J Hazard Mater. 2020;382:121040. https://doi. org/10.1016/j.jhazmat.2019.121040.

34.• Duan C, Ma T, Wang J, Zhou Y. Removal of heavy metals from aqueous solution using carbon-based adsorbents: a review. J Water Process Eng. 2020;37:101339 This article reviews 
various carbon-based adsorbents for the removal of heavy metals from water.

35. Siddiq O, Tawabini B, Soupios P, Ntarlagiannis D. Removal of arsenic from contaminated groundwater using biochar: a technical review. Int. J. Environ. Sci. Technol. 2020.

36. Alka S, Shahir S, Ibrahim N, Ndejiko MJ, Vo D, Manan FA. Arsenic removal technologies and future trends: a mini review. J Clean Prod. 2021;278:123805.

37. Maity J, Ho P, Huang Y, Sun A, Chen C, Chen C. The removal of arsenic from arsenic-bearing groundwater in in-situ and ex-situ environment using novel natural magnetic rock material and synthesized magnetic material as adsorbent: a comparative assessment. Environ Pollut. 2019;253:768-78. https://doi.org/10.1016/ j.envpol.2019.07.048.

38. Asadullah M, Jahan I, Ahmed MB, Adawiyah P, Malek NH, Rahman MS. Preparation of microporous activated carbon and its modification for arsenic removal from water. J Ind Eng Chem. 2020;20(3):887-96.

39. Callegari A, Ferronato N, Rada E, Capodaglio A, Torretta V. Assessment of arsenic removal efficiency by an iron oxidecoated sand filter process. Environ Sci Pollut Res. 2018;25(26): 26135-43. https://doi.org/10.1007/s11356-018-2674-y.

40. Prucek R, Jiri T, Jan K, et al. Ferrate(VI)-induced arsenite and arsenate removal by in situ structural incorporation into magnetic iron(III) oxide nanoparticles. Environ Sci Technol. 2013;47: 3283-92.

41. Feng L, Cao M, Ma X, et al. Superparamagnetic high-surface-area $\mathrm{Fe}_{3} \mathrm{O}_{4}$ nanoparticles as adsorbents for arsenic removal. J Hazard Mater. 2012;217:439-46.

42. Chowdhury S, Yanful E. Arsenic and chromium removal by mixed magnetite-maghemite nanoparticles and the effect of phosphate on removal. J Environ Manag. 2010;91:2238-47.

43. Nieto-Delgado C, Rangel-Mendez J. Anchorage of iron hydro(oxide) nanoparticles onto activated carbon to remove As(V) from water. Water Res. 2012;46:2973-82.

44. Xiong Y, Tong Q, Shan W, Xing Z, Wang Y, Wen S, et al. Arsenic transformation and adsorption by iron hydroxide/ manganese dioxide doped straw activated carbon. Appl Surf Sci. 2017;416:618-27.

45. Sharma S, Balasubramanian K, Arora R. Drinking water contamination and treatment techniques. Desalin Water Treat. 2016;57:1-17.

46. Hao L, Zheng T, Jiang J, et al. Removal of As(iii) from water using modified jute fibres as a hybrid adsorbent. RSC Adv. 2015;5:10723-32.

47. C'ardenas-Gonz'alez J, Acosta-Rodr'iguez I, T'eranFigueroa Y, et al. Bioremoval of arsenic (V) from aqueous solutions by chemically modified fungal biomass. 3 Biotech. 2017;7:226-34.

48. Hao L, Liu M, Wang N, Li G. A critical review on arsenic removal from water using iron-based adsorbents. RSC Adv. 2018;8:39545.

49. Targan S, Tirtom V. Arsenic removal from aqueous system using modified chestnut shell. Desalin Water Treat. 2014;56:1029-36.

50.• Guan Z, Lv J, Bai P, Guo X. Boron removal from aqueous solutions by adsorption - a review. Desalination. 2016;383:29-37 This article discusses in detail the adsorption techniques for removal of boron from water.

51. Chen T, Wang Q, Lyu J, Bai P, Guo X. Boron removal and reclamation by magnetic magnetite $(\mathrm{Fe} 3 \mathrm{O} 4)$ nanoparticle: an adsorption and isotopic separation study. Sep Purif Technol. 2020;231:115930. https://doi.org/10.1016/j.seppur.2019.115930.

52. Harada A, Takagi T, Kataoka S, Yamamoto T, Endo A. Boron adsorption mechanism on polyvinyl alcohol. Adsorption. 2011;17:171-8.

53. Harada A, Takagi T, Kawai A, Endo A. Effect of synthesis conditions of polyallylamine-beads-glucose (PAA-Glu) on boron adsorption. Adsorption. 2013;19:1-9.
54. Yavuz E, Gursel Y, Senkal B. Modification of poly(glycidyl methacrylate) grafted onto crosslinked $\mathrm{PVC}$ with iminopropylene glycol group and use for removing boron from water. Desalination. 2013;310:145-50.

55. Jalali M, Rajabi F, Ranjbar F. The removal of boron from aqueous solutions using natural and chemically modified sorbents. Desalin Water Treat. 2016) (in press). https://doi.org/10.1080/19443994. 2015.1020509.

56. Ozturk N, Kavak D. Boron removal from aqueous solutions by adsorption on waste sepiolite and activated waste sepiolite using full factorial design. Adsorption. 2004;10:245-57.

57. Ruiz M, Roset L, Demey H, Castro S, Sastre A, Pérez J. Equilibrium and dynamic studies for adsorption of boron on calcium alginate gel beads using principal component analysis (PCA) and partial least squares (PLS). Mater Werkst. 2013;44: 410-5.

58. Yuksel S, Yurum Y. Removal of boron from aqueous solutions by adsorption using fly ash, zeolite, and demineralized lignite. Sep Sci Technol. 2010;45:105-15.

59. Iizuka A, Takahashi M, Shibata E, Nakamura T, Yamasaki A. Boron removal performance of a solid sorbent derived from waste concrete. Ind Eng Chem Res. 2014;53:4046-51.

60. He J, Yang Y, Wu Z, Xie C, Zhang K, Kong L, et al. Review of fluoride removal from water environment by adsorption. J Environ Chem Eng. 2020;8:104516.

61. Zhou J, Liu Y, Han Y, Jing F, Chen J. Bone-derived biochar and magnetic biochar for effective removal of fluoride in groundwater: Effects of synthesis method and coexisting chromium. Water Environ Res. 2019;91(7):588-97. https://doi.org/10.1002/wer. 1068.

62. Pigatto R, Franco D, Netto M, Carissimi E, Oliveira L, Jahn S, et al. An eco-friendly and low-cost strategy for groundwater defluorination: adsorption of fluoride onto calcinated sludge. $\mathbf{J}$ Environ Chem Eng. 2020;8(6):104546. https://doi.org/10.1016/j. jece.2020.104546.

63.• Ayinde W, Gitari W, Munkombwe M, Amidou S. Green synthesis of $\mathrm{Ag} / \mathrm{MgO}$ nanoparticle modified nanohydroxyapatite and its potential for defluoridation and pathogen removal in groundwater. Phys Chem Earth. 2018;107:25-37. https://doi.org/10.1016/j.pce. 2018.08.007 This paper demonstrates the removal of both fluorides and pathogens using nanoparticles.

64. Borgohain X, Boruah A, Sarma G, Rashid M. Rapid and extremely high adsorption performance of porous $\mathrm{MgO}$ nanostructures for fluoride removal from water. J Mol Liq. 2020;305:112799 This paper has demonstrated very high adsorption capacity of $\mathrm{MgO}$ nanostructures for removal of fluoride from water.

65. Karmakar S, Dechnik J, Janiak C, De S. Aluminium fumarate metal-organic framework: a super adsorbent for fluoride from water. J Hazard Mater. 2016;303:10-20.

66. Kumari U, Behera S, Meikap B. A novel acid modified alumina adsorbent with enhanced defluoridation property: kinetics, isotherm study and applicability on industrial wastewater. J Hazard Mater. 2019;365:868-82.

67. Nehra S, Nair M, Kumar M. Hydrothermally shape-controlled synthesis of $\mathrm{TiO} 2 /$ Graphene for fluoride adsorption studies. J Chem Eng Data. 2019;64(12):5373-84.

68. Thathsara S, Cooray P, Mudiyanselage T, Kottegoda N, Ratnaweera D. A novel Fe-La-Ce tri-metallic composite for the removal of fluoride ions from aqueous media. J Environ Manag. 207(2-18):387-95.

69. Yu Z, Xu C, Yuan K, Gan X, Feng C, Wang X, et al. Characterization and adsorption mechanism of $\mathrm{ZrO} 2$ mesoporous fibers for health-hazardous fluoride removal. J Hazard Mater. 2018;346:82-92.

70. Xie D, Gu Y, Wang H, Wang Y, Qin W, Wang G, et al. Enhanced fluoride removal by hierarchically porous carbon foam monolith 
with high loading of UiO-66. J Colloid Interface Sci. 2019;542: 269-80.

71. Gao P, Tian X, Yang C, Zhou Z, Li Y, Wang Y, et al. Fabrication, performance and mechanism of $\mathrm{MgO}$ meso-/macroporous nanostructures for simultaneous removal of $\mathrm{As}(\mathrm{III})$ and $\mathrm{F}$ in a groundwater system. Environ Sci-Nano. 2016;3(6):1416-24.

72. Choong C, Kim M, Yoon S, Lee G, Park C. Mesoporous La/Mg/ Si-incorporated palm shell activated carbon for the highly efficient removal of aluminum and fluoride from water. J Taiwan Inst Chem Eng. 2018;93:306-14.

73. Raghav S, Kumar D. Comparative kinetics and thermodynamic studies of fluoride adsorption by two novel synthesized biopolymer composites. Carbohydr Polym. 2019;203:430-40.

74. Robshaw T, James A, Hammond D, Reynolds J, Dawson R, Ogden M. Calcium-loaded hydrophilic hypercrosslinked polymers for extremely high defluoridation capacity via multiple uptake mechanisms. J Mater Chem A. 2020;8(15):7130-44.

75. Nehra S, Raghav S, Kumar D. Biomaterial functionalized cerium nanocomposite for removal of fluoride using central composite design optimization study. Environ Pollut. 2020;258:113773.

76. He Y, Lin X, Yan T, Zhang X, Zhou J, Chena Y, et al. Selective adsorption of uranium from salt lake-simulated solution by phenolic-functionalized hollow sponge-like adsorbent. J Chem Technol Biotechnol. 2019;94:455-67.

77. Jiang X, Xiang X, Hu H, Meng X, Hou L. Facile fabrication of Biochar/A12O3 adsorbent and its application for fluoride removal from aqueous solution. J Chem Eng Data. 2019;64(1):83-9.

78. Mukhopadhyay K, Ghosh U, Sasikumar P. Enhanced capacity of fluoride scavenging from contaminated water by nanoarchitectural reorientation of cerium-incorporated hydrous iron oxide with graphene oxide. Environ Sci Pollut Res Int. 2019;26(25):26112-33.

79. Robshaw T, Tukra S, Hammond D, Leggett G, Ogden M. Highly efficient fluoride extraction from simulant leachate of spent potlining via La-loaded chelating resin. An equilibrium study. J Hazard Mater. 2019;361:200-9.

80. Tian Z, Gan Y. In situ synthesis of structural hierarchy flowerlike zeolite and its application for fluoride removal in aqueous solution. J Nanomater. 2019;2019:2932973.

81. Choong C, Wong K, Jang S, Nah I, Choi J, Ibrahim S, et al. Fluoride removal by palm shell waste based powdered activated carbon vs. functionalized carbon with magnesium silicate: implications for their application in water treatment. Chemosphere. 2020;239:124795.

82. Chatterjee S, Mukherjee M, De S. Defluoridation using novel chemically treated carbonized bone meal: batch and dynamic performance with scale-up studies. Environ Sci Pollut Res Int. 2018;25(18):18161-78.

83. Balarak D, Mahdavi Y, Bazrafshan E, Mahvi A, Esfandyari Y. Adsorption of fluoride from aqueous solutions by carbon nanotubes: determination of equilibrium, kinetic, and thermodynamic parameters. Fluoride. 2016;49(1):71-83.

84. Chi Y, Chen Y, Hu C, Wang Y, Liu C. Preparation of Mg-Al-Ce triple-metal composites for fluoride removal from aqueous solutions. J Mol Liq. 2017;242:416-22.

85. Chigondo M, Paumo H, Bhaumik M, Pillay K, Maity A. Hydrous $\mathrm{CeO} 2-\mathrm{Fe} 3 \mathrm{O} 4$ decorated polyaniline fibers nanocomposite for effective defluoridation of drinking water. J Colloid Interface Sci. 2018;532:500-16.

86. Ma A, Ke F, Jiang J, Yuan Q, Luo Z, Liu J, et al. Two lanthanidebased metal-organic frameworks for highly efficient adsorption and removal of fluoride ions from water. Crystengcomm. 2017;19(16):2172-7.

87. He J, Cai X, Chen K, Li Y, Zhang K, Jin Z, et al. Performance of a novelly-defined zirconium metal-organic frameworks adsorption membrane in fluoride removal. J Colloid Interface Sci. 2016;484: $162-72$.

88. Kang J, Gou X, Hu Y, Sun W, Liu R, Gao Z, et al. Efficient utilisation of flue gas desulfurization gypsum as a potential material for fluoride removal. Sci Total Environ. 2019;649:344-52.

89. He J, Chen K, Cai X, Li Y, Wang C, Zhang K, et al. A biocompatible and novelly-defined Al-HAP adsorption membrane for highly effective removal of fluoride from drinking water. J Colloid Interface Sci. 2017;490:97-107.

90. Dore E, Frau F. Calcined and uncalcined carbonate layered double hydroxides for possible water defluoridation in rural communities of the East African Rift Valley. J Water Process Eng. 2019;31: 100855.

91. Markeb A, Alonso A, Sanchez A, Font X. Adsorption process of fluoride from drinking water with magnetic core-shell $\mathrm{Ce}$ $\mathrm{Ti} @ \mathrm{Fe}_{3} \mathrm{O}_{4}$ and $\mathrm{Ce}-\mathrm{Ti}$ oxide nanoparticles. Sci Total Environ. 2017;598:949-58.

92.• Arancibia-Miranda N, Manquián-Cerda K, Pizarro C, Maldonado T, Suazo-Hernández J, Escudey M, et al. Mechanistic insights into simultaneous removal of copper, cadmium and arsenic from water by iron oxide-functionalized magnetic imogolite nanocomposites. J Hazard Mater. 2020;398:122940. https://doi.org/10.1016/j. jhazmat.2020.122940 This recent study demonstrates the removal of multiple contaminants from water using nanocomposites.

93. Khalfa L, Sdiri A, Bagane M, Cervera M. Multi-element modeling of heavy metals competitive removal from aqueous solution by raw and activated clay from the Aleg formation (Southern Tunisia). Int J Environ Sci Technol. 2020;17(4):2123-40. https://doi.org/10.1007/s13762-019-02614-x.

94. Bortone I, Santonastaso G, Erto A, Chianese S, Di Nardo A, Musmarra D. An innovative In-situ DRAINage system for advanced groundwater reactive TREATment (In-DRAIN-TREAT). Chemosphere. 2020;129412. https://doi.org/10.1016/j. chemosphere.2020.129412.

95. Abraham N, James J, Banerji T, Menon R. Development of a novel groundwater iron removal system using adsorptive $\mathrm{Fe}(\mathrm{II})$ process. Groundw Sustain Dev. 2020;10:100318. https://doi.org/ 10.1016/j.gsd.2019.100318.

96. Elkady M, Shokry H, Hamad H. Microwave-assisted synthesis of magnetic hydroxyapatite for removal of heavy metals from groundwater. Chem Eng Technol. 2017;41(3):553-62. https:// doi.org/10.1002/ceat.201600631.

97. Holmes R, Hart M, Kevern J. Reuse of drinking water treatment waste for remediation of heavy metal contaminated groundwater. Groundwater Monit Remed. 2019;39(4):69-79. https://doi.org/10. 1111/gwmr.12348.

98. Kuppusamy S, Palanisami T, Megharaj M, Venkateswarlu K, Naidu R. In-situ remediation approaches for the management of contaminated sites: a comprehensive overview. Rev Environ Contam Toxicol. 2016:1-115. https://doi.org/10.1007/978-3319-20013-2 1 .

99. Zhang B, Wang Z, Shi J, Dong H. Sulfur-based mixotrophic bioreduction for efficient removal of chromium (VI) in groundwater. Geochim Cosmochim Acta. 2020;268:296-309. https://doi.org/ 10.1016/j.gca.2019.10.011.

100. Falciglia P, Gagliano E, Brancato V, Finocchiaro G, Catalfo A, De Guidi G, et al. Field technical applicability and cost analysis for microwave based regenerating permeable reactive barriers (MW$\mathrm{PRBs}$ ) operating in Cs-contaminated groundwater treatment. J Environ Manag. 2020;260:110064. https://doi.org/10.1016/j. jenvman.2020.110064.

101. Maamoun I, Eljamal O, Falyouna O, Eljamal R, Sugihara Y. Multi-objective optimization of permeable reactive barrier design for $\mathrm{Cr}(\mathrm{VI})$ removal from groundwater. Ecotoxicol Environ Saf. 2020;200:110773. https://doi.org/10.1016/j.ecoenv.2020.110773. 
102. Faisal A, Abdul-Kareem M, Mohammed A, Naushad M, Ghfar A, Ahamad T. Humic acid coated sand as a novel sorbent in permeable reactive barrier for environmental remediation of groundwater polluted with copper and cadmium ions. J Water Process Eng. 2020;36:101373. https://doi.org/10.1016/j.jwpe.2020.101373.

103. Wen Z, Shan N, Bai Y, Yin L. The innovative application of agriculture straw in in situ field permeable reactive barrier for remediating nitrate-contaminated groundwater in grainproduction areas. Biochem Eng J. 2020;164:107755. https://doi. org/10.1016/j.bej.2020.107755.

104. Bilardi S, Calabrò P, Moraci N. The removal efficiency and longterm hydraulic behaviour of zero valent iron/lapillus mixtures for the simultaneous removal of $\mathrm{Cu}^{2+}, \mathrm{Ni}^{2+}$ and $\mathrm{Zn}^{2+}$. Sci Total Environ. 2019;675:490-500. https://doi.org/10.1016/j.scitotenv. 2019.04.260.

105. Nthunya L, Gutierrez L, Derese S, Nxumalo EN, Verliefde AR, Mamba BB, et al. A review of nanoparticle-enhanced membrane distillation membranes: membrane synthesis and applications in water treatment. J Chem Technol Biotechnol. 2019;94(9):275771. https://doi.org/10.1002/jctb.5977.

106. Drioli E, Ali A, Macedonio F. Membrane distillation: recent developments and perspectives. Desalination. 2015;356:56-84. https://doi.org/10.1016/j.desal.2014.10.028.

107. Zhang M, Liao B, Zhou X, He Y, Hong H, Lin H, et al. Effects of hydrophilicity/hydrophobicity of membrane on membrane fouling in a submerged membrane bioreactor. Bioresour Technol. 2015;175:59-67. https://doi.org/10.1016/j.biortech.2015.10.058.

108. Mishra S, Singh A, Singh J. Ferrous sulfide and carboxylfunctionalized ferroferric oxide incorporated PVDF-based nanocomposite membranes for simultaneous removal of highly toxic heavy-metal ions from industrial ground water. J Membr Sci. 2020;593:117422. https://doi.org/10.1016/j.memsci.2019. 117422.

109. Hubadillah S, Othman M, Ismail A, Rahman M, Jaafar J. A low cost hydrophobic kaolin hollow fiber membrane (h-KHFM) for arsenic removal from aqueous solution via direct contact membrane distillation. Sep Purif Technol. 2019;214:31-9. https://doi. org/10.1016/j.seppur.2018.04.025.

110. Manna A, Pal P. Solar-driven flash vaporization membrane distillation for arsenic removal from groundwater: experimental investigation and analysis of performance parameters. Chem Eng Process. 2016;99:51-7. https://doi.org/10.1016/j.cep.2015.10. 016.

111. Kim T, Kim T-K, Zoh K-D. Removal mechanism of heavy metal $(\mathrm{Cu}, \mathrm{Ni}, \mathrm{Zn}$, and $\mathrm{Cr})$ in the presence of cyanide during electrocoagulation using $\mathrm{Fe}$ and $\mathrm{Al}$ electrodes. J Water Process Eng. 2020;33:101109.

112. Ullah S, Faiz P, Leng S. Synthesis, mechanism, and performance assessment of zero-valent iron for metal-contaminated water remediation: a review. Clean - Soil, Air, Water. 2020;48(9): 2000080. https://doi.org/10.1002/clen.202000080.

113. Guan X, Sun Y, Qin H, Li J, Lo I, He D, et al. The limitations of applying zero-valent iron technology in contaminants sequestration and the corresponding countermeasures: the development in zero-valent iron technology in the last two decades (1994-2014). Water Res. 2015;75:224-48. https://doi.org/10.1016/j.watres. 2015.02.034.

114. Maitlo H, Kim K, Yang Park J, Hwan KJ. Removal mechanism for chromium (VI) in groundwater with cost-effective iron-air fuel cell electrocoagulation. Sep Purif Technol. 2019;213:378-88. https://doi.org/10.1016/j.seppur.2018.12.058.

115. Ajouyed O, Hurel C, Ammari M, Allal L, Marmier N. Sorption of $\mathrm{Cr}(\mathrm{VI})$ onto natural iron and aluminum (oxy)hydroxides: effects of $\mathrm{pH}$, ionic strength and initial concentration. J Hazard Mater. 2010;174(1-3):616-22. https://doi.org/10.1016/j.jhazmat.2009. 09.096 .
116. Peterson M, Brown G, Parks G, Stein C. Differential redox and sorption of $\mathrm{Cr}$ (III/VI) on natural silicate and oxide minerals: EXAFS and XANES results. Geochim Cosmochim Acta. 1997;61(16):3399-412. https://doi.org/10.1016/s0016-7037(97) 00165-8.

117. Amarine M, Lekhlif B, Mliji E, Echaabi J. Nitrate removal from groundwater in Casablanca region (Morocco) by electrocoagulation. Groundw Sustain Dev. 2020;11:100452. https://doi.org/10.1016/j.gsd.2020.100452.

118. Du X, Yang W, Zhang W, Wang Z, Nie J, Li G, et al. Removal of manganese, ferrous and antibiotics from groundwater simultaneously using peroxymonosulfate-assisted in-situ oxidation/ coagulation integrated with ceramic membrane process. Sep Purif Technol. 2020;252:117492. https://doi.org/10.1016/j. seppur.2020.117492.

119. Guo Y, Huang T, Wen G, Cao X. The simultaneous removal of ammonium and manganese from groundwater by iron-manganese co-oxide filter film: the role of chemical catalytic oxidation for ammonium removal. Chem Eng J. 2017:322-9.

120. Yang H-M, Park CW, Kim I, Yoon I-H, Sihn Y. Sulfur-modified chabazite as a low-cost ion exchanger for the highly selective and simultaneous removal of cesium and strontium. Appl Surf Sci. 2021;536:147776.

121. Ashfaq MY, Al-Ghouti MA, Qiblawey H, Zouari N, Rodrigues $\mathrm{DF}, \mathrm{Hu} \mathrm{Y}$. Isolation, identification and biodiversity of antiscalant degrading seawater bacteria using MALDI-TOF-MS and multivariate analysis. Sci Total Environ. 2019;656:910-20.

122. Hanafi M, Sapawe N. A review on the current techniques and technologies of organic pollutants removal from water/wastewater. Mater. 2021

123. Plewniak F, Crognale S, Rossetti S, Bertin PN. A genomic outlook on bioremediation: the case of arsenic removal. Front Microbiol. 2018;9:820. https://doi.org/10.3389/fmicb.2018.00820.

124. Crognale S, Casentini B, Amalfitano S, Fazi S, Petruccioli M, Rossetti S. Biological As(III) oxidation in biofilters by using native groundwater microorganisms. Sci Total Environ. 2019;651: 93-102. https://doi.org/10.1016/j.scitotenv.2018.09.176.

125. Shakya A, Ghosh P. Arsenic, iron and nitrate removal from groundwater by mixed bacterial culture and fate of arsenic-laden biosolids. Int J Environ Sci Technol. 2018;16(10):5901-16. https://doi.org/10.1007/s13762-018-1978-2.

126. Zhang Y, Jin F, Shen Z, Wang F, Lynch R, Al-Tabbaa A. Adsorption of methyl tert-butyl ether (MTBE) onto ZSM-5 zeolite: fixed-bed column tests, breakthrough curve modelling and regeneration. Chemosphere. 2019;220:422-31. https://doi.org/ 10.1016/j.chemosphere.2018.12.170.

127. Panousi E, Mamais D, Noutsopoulos C, Antoniou K, Koutoula K, Mastrantoni S, et al. Biological treatment of groundwater with a high hexavalent chromium content under anaerobic and anoxic conditions. J Chem Technol Biotechnol. 2016;91(6):1681-7. https://doi.org/10.1002/jctb.4973.

128. da Conceicao VM, Ugri MC, Silveira C, Nishi L, Vieira M, de Jesus BF, et al. Removal of excess fluoride from groundwater using natural coagulant Moringa oleifera Lam and microfiltration. Can J Chem Eng. 2014;93(1):37-45. https://doi.org/10.1002/cjce. 22101.

129. Carnevale B, Blanes P, Sala L, Bellu S. Removal of molybdate anions from contaminated waters by brown algae biomass in batch and continuous processes. J Chem Technol Biotechnol. 2016;92(6):1298-305. https://doi.org/10.1002/jctb.5124.

130. Aziz N, Jayasuriya N, Fan L, Al-Gheethi A. A low-cost treatment system for underground water using Moringa oleifera seeds and Musa cavendish peels for remote communities. J Chem Technol Biotechnol. 2020. https://doi.org/10.1002/jctb.6581 This research deals with the low-cost treatment system of groundwater. 
131. Al-Mamun A, Jafary T, Baawain M, Rahman S, Choudhury M, Tabatabaei M, et al. Energy recovery and carbon/nitrogen removal from sewage and contaminated groundwater in a coupled hydrolytic-acidogenic sequencing batch reactor and denitrifying biocathode microbial fuel cell. Environ Res. 2020;183:109273. https://doi.org/10.1016/j.envres.2020.109273.

132. Li S, Yang M, Wang H, Zhao Y. Dynamic characteristics of immobilized microorganisms for remediation of nitrogencontaminated groundwater and high-throughput sequencing analysis of the microbial community. Environ Pollut. 2020;267: 114875. https://doi.org/10.1016/j.envpol.2020.114875.

133. Mollamohammada S, Aly Hassan A, Dahab M. Immobilized algae-based treatment of herbicide-contaminated groundwater. Water Environ Res. 2020. https://doi.org/10.1002/wer.1405.

134. Zhou L, Xu X, Xia S. Effects of sulfate on simultaneous nitrate and selenate removal in a hydrogen-based membrane biofilm reactor for groundwater treatment: Performance and biofilm microbial ecology. Chemosphere. 2018;211:254-60. https://doi.org/10. 1016/j.chemosphere.2018.07.092.

135. Hao L, Liu Y, Chen N, Hao X, Zhang B, Feng C. Microbial removal of vanadium (V) from groundwater by sawdust used as a sole carbon source. Sci Total Environ. 2020;751:142161. https:// doi.org/10.1016/j.scitotenv.2020.142161.

136. Stokdyk J, Firnstahl A, Walsh J, Spencer S, de Lambert J, Anderson A, et al. Viral, bacterial, and protozoan pathogens and fecal markers in wells supplying groundwater to public water systems in Minnesota, USA. Water Res. 2020;178:115814.

137. Gallay A, Valk H, Cournot M, Ladeuil B, Hemery C, Castor C, Bon F, Me' graud F, Le Cann P, Desenclos J. A large multi- pathogen waterborne community outbreak linked to faecal contamination of a groundwater system, France, 2000. Clin Microbiol Infect 2006;12:561-570.

138. Hunt RJ, Johnson WP. Pathogen transport in groundwater systems: contrast with traditional solute transport. Hydrogeol J. 2017;25:921-30.

139.• Lambert J, Walsh J, Scher D, Firnstahl A, Borchardt M. Microbial pathogens and contaminants of emerging concern in groundwater at an urban subsurface stormwater infiltration site. Sci Total Environ. 2021;775:145738 This study deals with various microbial pathogens and contaminants found in groundwater.

140. Andreoli F, Sabogal-Paz L. Household slow sand filter to treat groundwater with microbiological risks in rural communities. Water Res. 2020;186:116352. https://doi.org/10.1016/j.watres.2020.116352.

141.• Alvear-Daza J, Sanabria J, Gutiérrez-Zapata H, Rengifo-Herrera J. An integrated drinking water production system to remove chemical and microbiological pollution from natural groundwater by a coupled prototype helio-photochemical $/ \mathrm{H}_{2} \mathrm{O}_{2} /$ rapid sand filtration/chlorination powered by photovoltaic cell. Sol Energy. 2018;176:581-8. https:// doi.org/10.1016/j.solener.2018.10.070 This article describes novel method for simultaneous removal of both chemical and microbial contaminants from groundwater.

142. Mpenyana-Monyatsi L, Mthombeni N, Onyango M, Momba M. Cost-effective filter materials coated with silver nanoparticles for the removal of pathogenic bacteria in groundwater. Int J Environ Res Public Health. 2012;9(1):244-71. https://doi.org/10.3390/ ijerph9010244.

143. Chung J, Foppen J, Gerner G, Krebs R, Lens P. Removal of rotavirus and adenovirus from artificial ground water using hydrochar derived from sewage sludge. J Appl Microbiol. 2015;119(3):876-84. https://doi.org/10.1111/jam.12863.

144. Obijole O, Gitari M, Mudzielwana R, Ndungu P, Samie A, Babatunde A. Hydrothermally treated aluminosilicate clay (HTAC) for remediation of fluoride and pathogens from water: adsorbent characterization and adsorption modelling. Ind: Water Res; 2021.
145. Ayinde W, Gitari W, Munkombwe M, Samie A, Smith J. Green synthesis of $\mathrm{AgMgOnHaP}$ nanoparticles supported on chitosan matrix: defluoridation and antibacterial effects in groundwater. $\mathrm{J}$ Environ Chem Eng. 2020;8(5):104026. https://doi.org/10.1016/j. jece.2020.104026.

146. Sivaselvam S, Premasudha P, Viswanathan C, Ponpandian N. Enhanced removal of emerging pharmaceutical contaminant ciprofloxacin and pathogen inactivation using morphologically tuned $\mathrm{MgO}$ nanostructures. J Environ Chem Eng. 2020;8:104256.

147. You J, Wang L, Zhao Y, Bao W. A review of aminofunctionalized magnetic nanoparticles for water treatment: features and prospects. J Clean Prod. 2021;281:124668.

148. Katata-Seru L, Moremedi T, Aremu O, Bahadur I. Green synthesis of iron nanoparticles using Moringa oleifera extracts and their applications: removal of nitrate from water and antibacterial activity against Escherichia coli. J Mol Liq. 2018;256:296-304. https:// doi.org/10.1016/j.molliq.2017.11.093.

149. Yousefi N, Lu X, Elimelech M, Tufenkji N. Environmental performance of graphene-based 3D macrostructures. Nature Nanotech. 2019;14:107-19. https://doi.org/10.1038/s41565-0180325-6.

150. Ali I, Basheer A, Mbianda X, Burakov A, Galunin E, Burakova I, et al. Graphene based adsorbents for remediation of noxious pollutants from wastewater. Environ Int. 2019;127:160-80. https:// doi.org/10.1016/j.envint.2019.03.029.

151. Yap P, Kabiri S, Auyoong Y, Tran D, Losic D. Tuning the multifunctional surface chemistry of reduced graphene oxide via combined elemental doping and chemical modifications. ACS Omega. 2019;4(22):19787-98. https://doi.org/10.1021/acsomega. $9 \mathrm{~b} 02642$.

152. Yap P, Nine M, Hassan K, Tung T, Tran D, Losic D. GrapheneBased sorbents for multipollutants removal in water: a review of recent progress. Adv Funct Mater. 2020;2007356. https://doi.org/ 10.1002/adfm.202007356.

153. Pan L, Wang Z, Yang Q, Huang R. Efficient removal of lead, copper and cadmium ions from water by a porous calcium alginate/graphene oxide composite aerogel. Nanomaterials. 2018;8(11):957. https://doi.org/10.3390/nano8110957.

154. Zare-Dorabei R, Ferdowsi S, Barzin A, Tadjarodi A. Highly efficient simultaneous ultrasonic-assisted adsorption of $\mathrm{Pb}(\mathrm{II}), \mathrm{Cd}(\mathrm{II})$, $\mathrm{Ni}$ (II) and $\mathrm{Cu}$ (II) ions from aqueous solutions by graphene oxide modified with $2,2^{\prime}$-dipyridylamine: central composite design optimization. Ultrason Sonochem. 2016;32:265-76. https://doi.org/ 10.1016/j.ultsonch.2016.03.020.

155. Alimohammady M, Jahangiri M, Kiani F, Tahermansouri H. Highly efficient simultaneous adsorption of $\mathrm{Cd}$ (ii), $\mathrm{Hg}$ (ii) and As(iii) ions from aqueous solutions by modification of graphene oxide with 3-aminopyrazole: central composite design optimization. New J Chem. 2017;41(17):8905-19. https://doi.org/10.1039/ c7nj01450c.

156. Pirveysian M, Ghiaci M. Synthesis and characterization of sulfur functionalized graphene oxide nanosheets as efficient sorbent for removal of $\mathrm{Pb}^{2+}, \mathrm{Cd}^{2+}, \mathrm{Ni}^{2+}$ and $\mathrm{Zn}^{2+}$ ions from aqueous solution: a combined thermodynamic and kinetic studies. Appl Surf Sci. 2018;428:98-109. https://doi.org/10.1016/j.apsusc.2017.09.105.

157. Upadhyay R, Soin N, Roy S. Role of graphene/metal oxide composites as photocatalysts, adsorbents and disinfectants in water treatment: a review. RSC Adv. 2014;4(8):3823-51. https://doi. org/10.1039/c3ra45013a.

158. Rinaudo J, Goerlach B. Economic assessment of groundwater protection (pp. 1-30). European Commission. 2003. Retrieved from https://ec.europa.eu/environment/water/water-framework/ pdf/gwd_economic_study.pdf

159. Environmental protection agency. Cost analyses for selected groundwater cleanup projects: pump and treat systems and 
permeable reactive barriers. 2001. Retrieved from https:/clu-in. org/download/remed/542r00013.pdf

160. Reddy KR. Physical and chemical groundwater remediation technologies. In: Darnault CJG, editors. Overexploitation and contamination of shared groundwater resources. NATO Science for Peace and Security Series C: Environmental Security. Springer, Dordrecht; 2008.
161. He C. Take a holistic approach to groundwater treatment. Opflow. 2015;41(11):22-5. https://doi.org/10.5991/opf.2015.41.0069.

Publisher's Note Springer Nature remains neutral with regard to jurisdictional claims in published maps and institutional affiliations. 